IRSH 58 (2013), pp. $285-325$ doi:10.1017/So0208590I 20008 I 8

(C) 2013 Internationaal Instituut voor Sociale Geschiedenis

\title{
SURVEY
}

\section{Writing a Global History of Convict Labour*}

\author{
Christian G. De Vito \\ International Institute of Social History, PO Box 2169, I000 CD \\ Amsterdam, The Netherlands \\ E-mail: christian.devito@gmail.com
}

\begin{abstract}
A L EX L I CHTENSTEIN
Department of History, Indiana University, 742 Ballantine Hall, I020 E. Kirkwood Ave, Bloomington, IN 4740I, USA
\end{abstract}

E-mail: lichtens@indiana.edu

\begin{abstract}
AвSTRACT: This bibliographic essay seeks to contribute to the understanding of convict labour from a global and long-term perspective. First the conditions conducive to the emergence and transformation of convict labour are addressed by framing this coercive labour form within broader classifications of labour relations and by discussing its connection with the problem of governmentality. Subsequently, an overview of the literature is undertaken in the form of a journey across time, space, and different regimes of punishment. Finally, the limitations of the available literature are discussed, the possibility of a longer-term (pre-1500) and global history of convict labour is considered, and some theoretical and methodological approaches are suggested that could favour this task.
\end{abstract}

\footnotetext{
* Draft versions of this article were discussed during the workshop on "Global Convict Labour" held at the International Institute of Social History, Amsterdam, I3-I4 June 2012, at a staff meeting at the IISH, and with individual experts. We should like to thank the following scholars for the comments, critiques, and suggestions they provided: Carlos Aguirre, Clare Anderson, Touraj Atabaki, Rossana Barragan, Stefano Bellucci, Aad Blok, Ulbe Bosma, Marc Buggeln, Timothy Coates, Francesca Di Pasquale, Miko Flohr, Guy Geltner, Miriam J. Groen-Vallinga, Karin Hofmeester, Stacey Hynd, Padraic Kenney, Margo De Koster, Marcel van der Linden, Jan Lucassen, Hamish Maxwell-Stewart, Klaus Mühlhahn, Robert Perkinson, Jean-Lucien Sanchez, Willem van Schendel, and Lynne Viola. An edited volume presenting contributions on the topic will be published in 2013 under the title "Global Convict Labour".
} 
Whatever their political perspective, historians of labour and work tend to associate the evolution of labour relations with the teleology of freedom. Various coercive labour practices - slavery, serfdom, indenture, vassalage - are regarded as giving way over time to free but commodified forms of labour, particularly with the expansion of capitalist modernity, free contract, and wage work. Yet, in nearly every society and in nearly every historical era, enforced work has in fact been deployed as a form of penal and/or administrative control of selected populations. Taking this perpetual nexus of labour and penality as its framework, this article examines the historically ubiquitous institution of convict labour from both a global and long-term perspective, and its place within a constellation of forms of unfree labour linked to the development of modernity. It does so in three main ways, corresponding to three mutually reinforcing sections of the bibliographic survey that follows.

In the first section, we frame convict labour within broader classifications of labour relations, in order to constitute penal work as a category of historical analysis, in much the same way as slavery, serfdom, wage labour, indentured labour, and so on have served as specific analytical categories and investigative tropes within labour historiography. Further, we point to the peculiar, socially constructed nature of the concept "convict", constituted as it is by legal regimes, state power, and private action that link unfreedom and punishment. Here we emphasize the need to address both the objective, structural factors that defined penal labour within a larger grid of relations of production and its subjective, experiential aspects by which prisoners defined their own consciousness. Finally, the question is raised of which conditions have proved most conducive to the emergence and transformation of convict labour over time, and the advantages of an approach that integrates economic, cultural, and political factors are underlined. In particular, we call attention to the role of penal labour in defining the nature of state power and in producing specific types of citizen and subject.

In the second section we provide a selective overview of some of the literature on convict labour in the form of an itinerary through time, space, and different regimes of punishment. By placing convict labour at the centre of our analysis, we aim to transcend the fragmentation of the existing historiography on the interconnections of labour, penality, and the denial of freedom. With this survey, the article points to the interconnections among different forms of punishment and the broader social, political, cultural, and economic context in which both penal labour and punishment more broadly have developed.

In the third and final section of the article we consider the possibility of a pre-capitalist longue durée of penal labour, extending our analysis prior to I 500, through a brief examination of transportation and imprisonment in ancient and medieval times. Moreover, we raise the question of how 
a genuinely global history of convict labour might be written, that is, a history that does not simply integrate existing knowledge and ongoing research on different parts of the world into pre-existing models of penal history, but that self-consciously looks for methodological approaches that avoid Eurocentric perspectives and point instead to transnational linkages as a constituent element in penal labour regimes.

\section{CLASSIFYING CONVICT LABOUR}

Convict labour can best be understood as a phenomenon located at the crossroads of two dynamic social processes: the commodification of labour and the enforced social definition of the "convict" as a person who has forfeited his or her right to freedom. Examination of the first process reminds us that convict labour has proved compatible with diverse modes of production and is perfectly compatible with modern social relations, such as the expansion of capitalism and the spread of wage labour. The second process calls attention to the importance of the state in shaping unfree labour relations, while also stressing subjective perceptions and representations of convict labour.

To frame convict labour within a broader history of labour relations, we might begin by considering the taxonomy constructed by the Global Collaboratory on the History of Labour Relations for a long-term project being conducted at the IISH "to establish a quantitative overview of labour relations worldwide for the period i 500-2000". In this context, convicts appear as two sub-categories of "tributary labourers": "forced labourers" and "tributary slaves". The former are defined as "those who have to work for the polity, and are remunerated mainly in kind", and include corvée labourers and conscripted soldiers as well as convicts. The "tributary slaves" are "those who are owned by and work for the polity indefinitely (deprived of the right to leave, to refuse to work, or to receive compensation for

I. K. Hofmeester and C. Moll-Murata (eds), The Joy and Pain of Work: Global Attitudes and Valuations, I500-1650, International Review of Social History, 56, Special Issue I9 (201 I). This special issue is dedicated to the Global Collaboratory project. See in particular the introduction by K. Hofmeester and C. Moll-Murata (pp. I-24). The taxonomy referred to in the text is published as Figure I, p. 6; the definitions of labour relations are published in the Appendix, pp. 2 I-23. See also the website: https://collab.iisg.nl/web/labourrelations.

2. "Tributary labourers" in general are defined as those who "are obliged to work for the polity (often the state, though it could also be a feudal or religious authority). Their labour is not commodified and owned by the polity." The taxonomy also allows one to frame non-working convicts within the category "non-working" and then under the sub-category "cannot work or cannot be expected to work". In this case the impossibility to work does not relate to either age, disability, or the need to study, but to the legal impossibility of working outside penal or administrative control and the material impossibility of working inside penal or administrative institutions. This condition, for instance, is largely diffused among inmates in many contemporary Western prisons. 
their labour)". The Global Collaboratory regards forced labourers in concentration camps as an example of these. The main advantage of this classification lies in the fact that it stresses the role of the state in the process of definition, selection, and exploitation of convict labour. However, this presents a serious limitation, since it almost exclusively underlines the otherness of convict labour in relation to the process of commodification of labour power. ${ }^{3}$ In so doing, it seems to leave little space for the understanding of those connections convict labour has maintained with other forms of free and unfree labour, setting it largely outside of important considerations of political economy.

A potentially more dynamic means of including convict labourers as part of the global working classes is provided by Marcel van der Linden in his collection of essays, Workers of the World. ${ }^{4}$ Van der Linden's work challenges the idea that only the labour power of free wage labourers is commodified, and thus opens up the possibility of considering various forms of both free and unfree labour as part of the process of commodification. By offering a far more supple definition of the "working class" than traditional Marxian accounts, one that is not dependent on the classic evolution of free wage labour and thus includes marginalized workers of all types, Van der Linden incorporates the experience of the majority of the population of the "Global South" into his account. In particular, he has

3. Another problem with this way of framing convict labour relates to the use of the concept of "slaves" for concentration camp prisoners. This association raises some fundamental issues that have been summarized by Marc Buggeln: ( $\mathrm{I}$ ) slavery is a system of labour in which the slave has a value for their private owner, while the concentration camp prisoner is the inmate of a state organization and is deprived of any (or a large part of his/her) value; (2) ex-concentration camp prisoners who defined themselves as slaves used the term in a non-economic, symbolic way; (3) much of the debate on the question "has rested on the absolute positioning of American slavery as the paradigmatic slave system for all times", while from a global and long-term perspective "slavery has proved to be an extremely multi-layered phenomenon that has shown itself capable of adapting to a wide variety of societal forms throughout history". In other words, even if one accepts that concentration camp prisoners were slaves, the question remains of what kind of slaves they were. For these reasons, Buggeln has pointed out that "the dangers implicit in this form of comparison [...] outweigh the benefits", and Rüdiger Hachtmann has stressed that "the term [slavery] is loaded with various connotations in historical research", and "cannot as a category really do justice to the specific forms of discrimination that the various groups of labourers compelled to unfree work deployments in German industry were subjected to during World War II". See M. Buggeln, "Were Concentration Camp Prisoners Slaves?: The Possibilities and Limits of Comparative History and Global Historical Perspectives", International Review of Social History, 53 (2008), pp. Io I-I 29, I I6 and I I 5 . See also W. Sofsky, The Order of Terror: The Concentration Camp (Princeton, NJ, 1997); R. Hachtmann, "Fordism and Unfree Labour: Aspects of the Work Deployment of Concentration Camp Prisoners in German Industry between 194I and 1944", International Review of Social History, 55 (2010), pp. $485-513,488-489$.

4. M. van der Linden, Workers of the World (Leiden, 2008). See especially ch. 2, and particularly pp. I $8-20$ and 34 . 
distinguished four different types of possible labour commodification: "autonomous commodification, in which the carrier of labour power is also its possessor, and heteronomous commodification, in which the carrier of labour power is not its possessor; in both cases, the carrier's labour power can be offered by the carrier him- or herself or by another person". Most importantly for our purposes, Van der Linden identifies the "coerced commodification of labour power" as an important aspect of the making of a global working class. Indeed, using this model, convict labour can be considered as commodified labour insofar as the labour power of the convicts - who are carriers but not possessors of their labour power - is commodified by the authorities, under whose penal and/or administrative control they are held (at least initially).

The classification proposed by Van der Linden has a fundamental advantage in that it allows us to envisage convict labour in its connections with other forms of free and unfree labour rather than setting it off as an anomalous category. In so doing, it supplements the first classification proposed by the Collaboratory, joining in that project's effort to identify a global working class while recognizing the close ties between penality and the historical experience of labour and work in many contexts, including the commodification of labour. As we will argue in the following section, convict labour has been a part of fluid coercive networks in the context of early modern and modern colonial empires as well as in more recent and even contemporary labour systems. Empirical research has repeatedly shown its multiple intertwining with other forms of unfree labour as well as with free labour. In fact, in many penal colonies convicts prepared the ground for indentured and free labour, indentured workers became convicts when caught after trying to escape or as a supplementary punishment, slaves and free workers condemned to death could be "liberated" upon transportation, and ex-convicts sometimes signed contracts of indenture or migrated on to new destinations. ${ }^{5}$

Nor is convict labour imbricated with other labour relations only on a structural level. Although a very complex topic for research, convicts' self-perception of their work also plays an important role here. This is the case, for example, with some ex-concentration camp prisoners who tried to make sense of their experience by evoking slavery. With reference to

5. C. Anderson, Subaltern Lives: Biographies of Colonialism in the Indian Ocean, World, I790-1920 (Cambridge, 20I2). See also U. Bosma, "European Colonial Soldiers in the Nineteenth Century: Their Role in White Global Migration and Patterns of Colonial Settlement", Journal of Global History, 4 (2009), pp. 317-336. On p. 319 the author refers to the cases of Siberia and Australia and explicitly points to the fact that "[i]n the early phases of colonialism, soldiers and convicts were, if not the cheapest, certainly the most easily deployed source of labour in the extreme circumstances of a frontier". The two groups thus came to play a pivotal role as "primers of the pump for mass migration" and in preparing the ground for other forms of labour. 
another context, Clare Anderson has shown that prisoners transported within the Indian Ocean sometimes did not perceive themselves as convicts at all and associated their experience with that of indenture, a status more common in their own families and communities. And a deep tradition of African-American cultural expression has made the convict labourer a central character in the longing for liberation in a society marked by racial repression. ${ }^{6}$

Such subjectivity plays an especially important role in the case of convict labour, given its very nature. Besides the commodification of labour, the process of defining the "convict" is the other social dynamic that shapes convict labour. While concepts such as wage labour or indentured work directly point to particular forms of labour relations rooted in contract, ${ }^{7}$ the expression "convict labour" points to an immanent labour relation into which individuals enter only after they have undergone a process of enforced social definition as convicts, a social definition that brands them as criminals, deviants, or non-citizens in need of isolation and correction. Therefore, although economic rationales have sometimes played a fundamental role in defining the geography and morphology of punishment and work, the impact of legal and administrative categories on these processes should never be underestimated. Moreover, since punishment (and sometimes other administrative forms of control) usually implies a definite amount of time, the experience of convict labour represents only a limited portion of the convict's life experience. Being a convict is often a temporary juridical or administrative status that eventually entails the reintegration of the prisoner into specific labour relations. It can be expected therefore that the convict's labour identity and ethics either remain connected to a previous occupation (or non-occupation) and location in the labour market and social order, or are projected after the end of punishment, as in the case of many transported convicts who subsequently settled in the new penal colonies.

6. Anderson, Subaltern Lives. On subjectivity and the memory of imprisonment and forced labour, see also J.M. Gheith and K.R. Jolluck, Gulag Voices: Oral Histories of Soviet Incarceration and Exile (New York, 20I I); on the African-American experience, see L. Gellert, Negro Songs of Protest (New York, 1936); B. Jackson, Wake Up, Dead Man: Afro-American Work Songs from Texas Prisons (Cambridge, MA, 1972); and H.B. Franklin, Prison Literature in America: The Victim as Criminal and Artist (New York, I989).

7. However, an extended literature has discussed the need to overcome a rigid distinction between "free" and "unfree" labour and has even questioned the category of "free labour". See especially G. Prakash, "Colonialism, Capitalism and the Discourse of Freedom", in S. Amin and M. van der Linden (eds), "Peripheral" Labour? Studies in the History of Partial Proletarianization (Cambridge, 1997), pp. 9-25; T. Brass and M. van der Linden (eds), Free and Unfree Labour: The Debate Continues (Berne, I997); R.P. Behal, "Changing Paradigm of South Asian Labour Historiography", in M. van der Linden and E. Himmelstoss (eds), Labour History Beyond Borders: Concepts and Explorations (Vienna, 2009), pp. 63-78; Van der Linden, Workers of the World. 
Moreover, not only juridical and administrative factors, but also social, political, economic, and cultural processes are involved in the definition of "convict" (as well as in that of related concepts such as prisoner, internee, and inmate). As the sociology of punishment and the critical approaches to criminology have stressed, even in the highly formalized legal systems of contemporary democracies, political and media discourses on criminality, race, and security shape ideologies of punishment. The possibility of accessing the right of defence, the structure of penal codes and juridical administration, and the mentality of police, social, judicial, and penal actors all play a decisive role in the social construction of deviancy, crime, and convicts. ${ }^{8}$ It seems safe to assume that this discretionality increases in the case of medieval and early modern contexts, where informal agencies and extrajudicial mechanisms played a fundamental role in punishment, and that it reaches its zenith in the case of administrative measures taken under "states of exception", especially in situations of war, colonization, and non-democratic regimes, that is, in most of the situations where convict labour has actually appeared in history. In democratic societies, such exceptionality may still be associated with the perpetuation of historical, racial, or ethnic domination, as seems to be the case for the current world leader in incarceration, the United States. ${ }^{9}$

For these reasons, while we might still want to build a taxonomy of labour relations that includes convict labour and allows quantitative comparative insights, in trying to make sense of convict labour any reification of the phenomenon should be avoided. One possible way to proceed is through a double move. On the one hand, we propose to define convict labour loosely as the work performed by individuals under penal and/or administrative control. This broad definition binds together different institutions across various periods and within all sorts of political regime. At the same time, it clearly differentiates convict labour from other historical situations where either forced labour or penal and/or administrative control were present, but did not come together. For instance, slavery or POW labour as such are clearly separated from convict labour; the work performed by slaves and POWs is considered convict labour here only insofar as it is enforced as the consequence of a supplementary penal or administrative measure (for example, as a punishment for a crime or a disciplinary infraction). Beyond this separation, however, areas of interpenetration between convict labour and other forms of forced labour become visible and can be addressed in

8. See for instance P. Combessie, Sociologie de la prison (Paris, 200I); K. Carrington and R. Hogg, Critical Criminology: Issues, Debates, Challenges (Portland, OR, 2002).

9. M. Alexander, The New Jim Crow: Mass Incarceration in the Age of Colorblindness (New York, 2010). 
empirical research. ${ }^{10}$ Ultimately, because of its pragmatic rather than prescriptive approach, this definition points to the fact that the question "What is convict labour?" can be answered only with reference to specific historical contexts. On the other hand, with the goal of generalizing the findings of localized studies, the question "Why convict labour?" could be asked, or, to put it another way, empirical findings could be used to generalize about the historical conditions under which convict labour has been produced and exploited in the larger process of the commodification of labour.

Such a procedure entails understanding convict labour not in isolation but as part of an integrated labour market, that is, in dialectic with other (free and unfree) labour relations and their mutual combinations. And it requires an approach that brings together different strands of the literature that have stressed either economic explanations or socialpolitical-cultural factors, such as racial or colonial domination. As in the pioneering work of Georg Rusche and Otto Kirchheimer, the significance of economic approaches to punishment lies in pointing to the connection between economic cycles, incarceration, and convict labour. ${ }^{\text {II }}$ Their approach prompts consideration of the place of convict labour in the labour market of particular economic sectors, the disciplining effect of convict labour on the free workforce, the productivity of convict labour, and so on. However, in order to avoid deterministic economic explanations, the importance of other factors also needs to be recognized. The function of convict labour, its characteristics, and its connection with other forms of labour relations have depended not just on rational economic motivations but also on social constructions that have influenced both the way the convicts have been imagined, selected, and

Io. Think, for instance, of the many cases, especially in non-Western European contexts, where labour was imposed on individuals through extra-judicial practice within households, communities, and guilds. Another case is that of the "free convicts" in the late I950s and I960s Chinese laogai, that is, individuals who had formally completed their sentences but were prevented from leaving the camps and forced to work in special brigades under the jiu ye system of "job placement".

I I. The key reference for this approach is still G. Rusche and O. Kirchheimer, Punishment and Social Structure (New York, 1939). The thesis had already been anticipated in G. Rusche, "Arbeitsmarkt und Strafvollzug. Gedanken zur Soziologie der Strafjustiz", Zeitschrift für Sozialforschung (1933), pp. 63-78. For more recent studies restating this materialist explanation, see D. Melossi and M. Pavarini, Carcere e fabbrica: alle origini del sistema penitenziario (XVI-XIX secolo) (Bologna, 1977), English translation: The Prison and the Factory: Origins of the Penitentiary System (London, I98I); I. Jankovich, "Labor Market and Imprisonment", Crime and Social Justice, 8 (1977), pp. 17-31; M. Killias and C. Grandjean, "Chômage et taux d'incarcération: l'exemple de la Suisse de I 890 à I94I", Déviance et société, Io (I986), pp. 309-322; B. Laffargue and T. Godefroy, "La prison républicaine et son environment économique. Population en prison et marché du travail (1870-1914)", Déviance et société, I4 (1990), pp. 39-58. 
differentiated, and the forms of punishment, the related institutions, and their localization. Discourses of ethnicity, race, class, and gender, in particular, have shaped notions of criminality as a whole and the lives of individuals under penal and administrative control. Precisely because coercive networks are highly differentiated and fluid, the coexistence of different forms of punishment has been possible and "rehabilitative" and "punitive" work have coexisted in differentiated parts of the convict population, in differentiated spaces, and at different times in the biography of a single individual.

Thinking about these non-economic aspects of convict labour brings us back to the widely influential question of "governmentality", a concept coined by Foucault in the late I970s, and central to the subsequent deployment of Foucauldian accounts of the role of incarceration in constituting modern forms of state power. From this vantage point, historians might consider how different types of penal labour regime have served as an expression and projection of particular forms of bio-political sovereignty, one that can knit together conceptualizations of citizenship (or non-citizenship), work, and the legal (or extra-legal) power to punish at particular historical moments. Who is defined as "criminal" and why, how the state commands prisoners' capacity for productive labour and in what form, and how such unfree labour is conceptualized as part of a larger social order all deserve further historical scrutiny. ${ }^{\mathrm{I} 2}$

Nevertheless, in understanding how economic, political, social, and cultural factors have shaped the penal strategies of empires, states, and local authorities, the limits of governmentality also need to be investigated, as even Foucault himself came to acknowledge. ${ }^{13}$ After all, even the most powerful authority has neither ever had an actual monopoly on social control and coercive discourses nor unlimited resources to implement them. Shifts from prisons to labour camps, for instance, have also stemmed from concrete problems such as systematic overcrowding, fiscal limitations, inadequate prison buildings, and the (perceived) lack of professional training of prisoners and guards. Similarly, the low productivity of convict labour, often exacerbated by prisoner resistance, has sometimes modified and even stopped plans for economic exploitation, transforming the everyday reality of many prisons and penal colonies into "a simple struggle for financial selfsufficiency". ${ }^{14}$ Nor should governmentality be regarded as an ahistorical

I 2. M. Foucault, "Governmentality", in G. Burchell, C. Gordon, and P. Miller (eds), The Foucault Effect: Studies in Governmentality (Chicago, IL, I99I), pp. 87-104. See especially Foucault's useful definition on p. I02.

I3. Burchell, Gordon, and Miller, The Foucault Effect, p. 5.

I4. Taylor C. Sherman, "Tensions of Colonial Punishment: Perspectives on Recent Developments in the Study of Coercive Networks in Asia, Africa and the Caribbean”, History Compass, 7 (2009), pp. 659-677, 661. 
and impersonal force; in this respect, investigations of the agency of the historical actors need to be systematically extended.

Drawing on the classificatory model we sketch above, the following two sections address the available literature on convict labour. In the next section of this article we attempt to survey this literature. In doing so, we make no claim for completeness, not least because of limited space, the need for selection, and the disproportionate reference to scholarship in English. We aim rather to show the potentiality of the concept of convict labour for bringing together different strands of literature that have so far largely remained separated. ${ }^{\mathrm{IS}}$ We therefore bind together knowledge and issues stemming from, among other areas of scholarship, the history of the penitentiary, the history of transportation, the history of the Nazi camps, Gulag studies, and the sociology and criminology of contemporary punishment. In the third and final section we attempt a synthesis of this literature as a model of global convict labour history, rather than from the perspective of each fragmented sub-discipline. We point to its main limitations and gaps and, in so doing, we seek to provide an agenda for future research in this field.

\section{A GLOBAL SURVEY OF CONVICT LABOUR}

One of the earliest deployments of convict labour came in maritime transport and naval combat. Yet, contrary to a widespread popular image, no convict rowers were chained to the oars of the galleys during the Roman Empire - with the exception of Ptolemaic Egypt - and their use was also largely limited aboard early fourteenth-century Venetian and fifteenth-century Florentine galleys and in the navy of the Ottoman sultan Suleiman the Magnificent in the early sixteenth century. ${ }^{16}$ While prisoners

I 5. For a similar approach, see P. Spierenburg, The Prison Experience: Disciplinary Institutions and Their Inmates in Early Modern Europe (New Brunswick, NJ [etc.], I99I), ch. II, pp. $26 \mathrm{I}-276$.

I6. On convict labour aboard galleys, see Paul Walden Bamford, "The Procurement of Oarsmen for French Galleys, I660-1748", American Historical Review, 65 (1959), pp. 3 I-48; Lionel Casson, "Galley Slaves", Transactions and Proceedings of the American Philological Association, 97 (1966), pp. 35-44; M.E. Mallet, The Florentine Galleys in the Fifteenth Century (Oxford, 1967); I.A.A. Thompson, "A Map of Crime in Sixteenth-Century Spain”, Economic History Review, 2 I (1968), pp. 244-267; Henry Kamen, "Galley Service and Crime in SixteenthCentury Spain”, Economic History Review, 22 (1969), pp. 304-305; L. Casson, Ships and Seamanship in the Ancient World (Princeton, NJ, 1971); P.W. Bamford, Fighting Ships and Prisons: The Mediterranean Galleys of France in the Age of Louis XIV (London, 1974); L.T. Lehmann, Galleys in the Netherlands (Amsterdam, I984); L. Casson, The Ancient Mariners: Seafarers and Sea Fighters of the Mediterranean in Ancient Times (Princeton, NJ, 1991); Colin Imber, "The Navy of Suleyman the Magnificent", Archivum Ottomanicum, 6 (1980), pp. 21 I-282; J.S. Morrison and R. Gardiner (eds), The Age of the Galley: Mediterranean Oared Vessels Since Pre-Classical Times (London, 1995); J.F. Guilmartin, Galleons and Galleys 
of war were sometimes used as galley slaves, the use of "free" (that is, conscripted or hired) rowers was largely preferred, not least because unlike prisoners they could be armed. It was the growing difficulty of sustaining galley costs that led private and state actors to turn to slaves and convicts during the sixteenth and seventeenth centuries. Only then did the degredados, together with slaves in Asia and Brazil, become essential on Portuguese galleys, and the forzados, consisting mainly of vagabonds, gypsies, and moriscos, come to make up the majority of workmen on Spanish galleys.

In the French case the use of convict labour on the galleys reached its climax in the second half of the seventeenth century. ${ }^{17}$ Slaves - mainly North Africans (called Turks), but at times also schismatic Russians and Greeks, West Africans, and American Iroquois Indians - acted as the elite among the rowers. Lower in the rank stood the unskilled mass of the forçats, condemned to the galley à perpetuité or for a fixed period for crimes such as bigamy, theft, blasphemy, vagabondage, and mendicancy, and for their belonging to the so-called Religion pretendue reformée after the revocation of the Edict of Nantes in 1685 . In order to counter the shortage of manpower, in the mid-I680s the service was reorganized by the Secretary of State for the Navy, Jean-Baptiste Colbert, with 4,870 new forçats and I,40I new slaves joining the forty galleys of the French fleet. By the early eighteenth century, however, galleys were phased out in favour of the technical superiority and the higher firepower of naval sailing ships. When the Corps des Galères was officially abolished in 1748 "its few remaining vessels were essentially prison hulks for the accommodation of convicts who slept aboard, and usually worked ashore by day". ${ }^{8}$ The hulks harboured in the London docks in the same period had the same function.

A similar trajectory of galley service can be observed in the Islamic empires. As Anthony Gorman has argued, in the sixteenth century penal or forced labour (sukhri or tashkir) was employed especially by the Ottomans "when the need for oarsmen saw service in the galleys (kürek) commonly prescribed as a punishment". ${ }^{19}$ Three centuries later, however, sentence to the galleys had been transformed into work in agriculture and

(London, 2002); L. Lo Basso, Uomini da remo. Galee e galeotti del Mediterraneo in età moderna (Milan, 2003); M. Capulli, Le Navi della Serenissima - La "Galea" di Lazise (Venice, 2003); Anthony Gorman, "Regulation, Reform and Resistance in the Middle Eastern Prison", in F. Dikötter and I. Brown (eds), Cultures of Confinement: A History of the Prison in Africa, Asia, and Latin America (Ithaca, NY, 2007), pp. 95-146.

I7. See especially Bamford, "The Procurement".

I8. Ibid., p. 47.

19. Gorman, "Regulation, Reform and Resistance in the Middle Eastern Prison", p. ir8. Further information in the text is also taken from this essay. 
small-scale industry. Together with free labour, this "employment with chained feet" played a significant role in Muhammad Ali's programme of "modernization" in early nineteenth-century Egypt.

Thus, the sectoral deployment of penal labour often shifted according to shifts in political economy. Besides galley service and public works, penal servitude developed in the early modern period, especially in the form of transportation, to aid in populating and securing newly acquired imperial territory. ${ }^{20}$ The rise of the Iberian empires typically involved a shift from presidios along the borders of Spain and Portugal to locations overseas. In the case of Portugal, havens and exile locales at home were phased out (with the exception of Castro Marim) and, according to Timothy Coates, at least 50,000 convicts and sinners were forced to relocate, largely overseas, in the early modern period. ${ }^{2 \mathrm{I}}$ Their destinations were mainly the new colonies in Goa, coastal West Africa (Azores, Madeira,

20. On early modern transportation in the Portuguese and Spanish empires see Ruth Pike, "Penal Labor in Sixteenth-Century Spain: The Mines of Almadén", Societas - A Review of Social History, 3 (1973), pp. 193-206; idem, "Penal Servitude in the Spanish Empire: Presidio Labor in the Eighteenth Century", Hispanic American Historical Review, 58 (I978), pp. 2 I-40; idem, Penal Servitude in Early Modern Spain (Madison, WI, I983); E. Troconis de Veracoechea, Historia de las cárceles en Venezuela, I600-1890 (Caracas, I983); M.A. Lima Cruz, "Exiles and Renegades in Early Sixteenth Century Portuguese India", Indian Economic and Social History Review, 23 (1986), pp. 249-262; F. Pico, El dia menos pensado: historia de los presidiarios en Puerto Rico, 1793-1993 (Rió Piedras, 1994); Timothy Coates, "Crime and Punishment in the Fifteenth-Century Portuguese World: The Transition from Internal to Imperial Exile", in Donald Kagay and L.J. Andrew Villalon (eds), The Final Argument: The Imprint of Violence on Society in Medieval and Early Modern Europe (London, 1998), pp. I 19-I39; G. Haslip-Viera, Crime and Punishment in Late Colonial Mexico City, I692-1810 (Albuquerque, NM, I999); M.L. Bush, Servitude in Modern Times (Cambridge, 2000); T. Coates, Convicts and Orphans: Forced and State-Sponsored Colonizers in the Portuguese Empire, I550-1755 (Stanford, CA, 200I); G. Pieroni and T. Coates, De couto do pecado ecvila do sal: Castro Marim, I550-1850 (Lisbon, 2002); Timothy Coates, "The Early Modern Portuguese Empire: A Commentary on Recent Studies", Sixteenth Century Journal, 37 (2006), pp. 83-90; idem, "European Forced Labor in the Early Modern Era", in David Eltis and Stanley L. Engerman (eds), The Cambridge World History of Slavery (Cambridge, 20II), III, pp. 63I-649. On the penal servitude of Christians caught by North African pirates, see Ellen Friedman, "North African Piracy on the Coasts of Spain in the Seventeenth Century: A New Perspective on the Expulsion of the Moriscos", International History Review, I (1979), pp. I-I6. For a broader discussion of piracy and early modern empire, see Linda Colley, Captives: Britain, Empire, and the World, I600-I 850 (London, 2002). The question of the way empires have been populated has been central in the "New Imperial Histories", although these studies have rarely addressed convict labour directly. For an introduction see F. Cooper and A.L. Stoler (eds), Tensions of Empire: Colonial Cultures in a Bourgeois World (Berkeley, CA [etc.], 1997); I. Gerasimov et al., "In Search of a New Imperial History", Ab Imperio, I (2005), pp. 33-56; K. Wilson, "Old Imperialisms and New Imperial Histories: Rethinking the History of the Present", Radical History Review, 95 (2006), pp. 2 I-234; S. Howe (ed.), The New Imperial Histories Reader (London, 2008).

21. Coates, Convicts and Orphans; Pieroni and Coates, Castro Marim. 
Principe, São Tomé, and Cape Verde) and later, between 1740 and I 822 , Pará, Maranhão, and Santa Catarina in Brazil. In the Spanish case, the mercury mines of Almadén and the maritime arsenal of Cartagena, La Carraca (Cadiz), and El Ferrol (Galicia) and the northern African presidios of Oran, Ceuta and Melilla, Peñón de Vélez, and Peñón de Alhucemas continued to host presidiarios involved in the heavy manual work of constructing, repairing, and maintaining roads, canals, fortifications, and other military facilities. To these, the Filipino presidios and then increasingly the Spanish American presidios were added.

Punishment, transportation, and penal labour all played instrumental roles in the capacity of the Iberian empires to expand their global frontiers, gain access to economic resources, and extend their political and military reach in this period. ${ }^{22}$ Similarly, the Dutch convict transportation system played an integral role in linking distant imperial outposts. In this case, however, most traffic in forced labour was overseen by a private entity, the Dutch East India Company (VOC), which controlled the Indian Ocean flow of convicts between Batavia and the Cape of Good Hope in southern Africa. As Kerry Ward has shown, transported convict labour proved important to the "networks of empire" thrown across various territories by the VOC, which in doing so helped constitute "multiple and intersecting fields of partial sovereignty". ${ }^{23}$

Security and penal considerations played a significant role in the matching of prisoners and destinations. For instance, Ruth Pike has noted that in the Spanish Empire recidivist prisoners were less likely to be sent to north Africa, while deserters were shipped mainly to the New World. ${ }^{24}$ However, the labour needs of the various presidios represented the general guiding principle for the choice of destination. Moreover, while penal servitude in metropolitan Spain was exclusively linked to the state's economic interests, in Spanish America, prisoners sentenced to hard labour by the colonial courts were also leased to private employers who used them in mines, manufactures, and mills, eventually to compensate for the severe shortage of labour due to the decline in the Indian population from the mid-sixteenth century. Particularly after Spain's losses to England during the Seven Years War (1756-1763), some hundreds of convicts together with black slaves, their number progressively diminishing as that of convicts grew - were also involved in the fortification of Latin American ports such as Havana (Cuba) and San Juan (Puerto Rico). Havana served as the main hub for the New World presidios, and presidiarios came there

22. This argument complements that made by Robin Blackburn in The Making of New World Slavery: From the Baroque to the Modern, I492-I800 (London, 1998).

23. K. Ward, Networks of Empire: Forced Migration in the Dutch East India Company (Cambridge, 2008), p. 6.

24. See especially Pike, Penal Servitude in Early Modern Spain. 
from Mexico as well as from Spain. In Spain, following a system devised in the sixteenth century to supply convict rowers for the galleys, convicts awaited transportation to Spanish America in the central prisons of Toledo, Valladolid, and Seville and were shipped mainly through the port of Cadiz. Since they could be sent only on warships carrying troops, they often had to wait for years in the special depósito of La Carraca, subject to the informal practice, contrary to existing legislation, of exploiting the labour of convicts awaiting transportation.

In colonial settings, penal servitude was an integral part of a broader system of legal bondage that included slavery, serfdom, indentured service, and debt bondage, in which "unfree" labour played a fundamental role in the transition to "modernity". ${ }^{25}$ Between 1607 and 1775, 54,500 convicts from England, Wales, Ireland, and Scotland crossed the Atlantic Ocean to reach the shores of the British colonies in North America. ${ }^{26}$ Together with more than 310,000 African slaves, around 200,000 British, Dutch, German, and French indentured workers and around the same number of free European migrants they formed the "many-headed hydra" of a nascent Atlantic working class that Peter Linebaugh and Marcus Rediker have described in their volume of that title. ${ }^{27}$ However, the independence of the American colonies deeply altered this trend. Already between I 776 and I809, while I I4,600 African slaves still reached North American shores, the number of free migrants along the same route rose to more than 250,000 , while that of indentured servants and convicts dropped to 18,300 and $\mathrm{I}, 000$ respectively. In the following decennium

25. See Bush, Servitude in Modern Times; David Eltis (ed.), Coerced and Free Migration: Global Perspectives (Stanford, CA, 2002); E. Christopher, C. Pybus, and M. Rediker (eds), Many Middle Passages: Forced Migration and the Making of the Modern World (Berkeley, CA, 2007). The perspective of studying global migrations beyond the traditional focus on "free" migration is a central element of global migration history. See, for instance, D. Hoerder, Cultures in Contact: World Migrations in the Second Millennium (Durham, NC [etc.], 2002); J. Lucassen and L. Lucassen, "The Mobility Transition Revisited, I 500-1900: What the Case of Europe Can Offer to Global History", Journal of Global Labour History, 4 (2009), pp. 347-377; J. Lucassen, L. Lucassen, and P. Manning (eds), Migration History in World History: Multidisciplinary Approaches (Leiden [etc.], 2010); J. Lucassen, "From Mobility Transition to Comparative Global Migration History”, Journal of Global History, 6 (201 I), pp. 299-307; U. Bosma, G. Kessler, and L. Lucassen (eds), Migration and Membership Regimes in Global and Historical Perspective (Leiden [etc.], forthcoming); D. Gabaccia and D. Hoerder (eds), Connecting Seas and Connected Ocean Rims: Indian, Atlantic, and Pacific Oceans and China Seas Migrations from the I830s to the I930s (Leiden [etc.], 20I I). It should be noted, however, that up to this point these studies have paid only marginal attention to convict migration.

26. Aaron S. Fogleman, "From Slaves, Convicts, and Servants to Free Passengers: The Transformation of Immigration in the Era of the American Revolution", Journal of American History, 85 (1998), pp. 43-76. See also R.A. Ekirch, Bound for America: The Transportation of British Convicts to the Colonies, I7I8-I775 (Oxford, 1987); D. Jordan and M. Walsh, White Cargo: The Forgotten History of Britain's White Slaves in America (London, 2008).

27. P. Linebaugh and M. Rediker, The Many-Headed Hydra: Sailors, Slaves, Commoners, and the Hidden History of the Revolutionary Atlantic (Boston, MA, 2000). 
the transportation of convicts to North America virtually stopped, and the Australian continent became Britain's favoured penal destination.

In a new ideological climate that increasingly placed a premium on the ideal of "free labour", religious and scientific motivations and the economic interests of a part of the elite produced the rise of the penitentiary in the north-eastern American states during the nineteenth century. ${ }^{28}$ In the debate between the supporters of the Pennsylvania model (continuous isolation and work confined to single-prisoner cells) and those of the Auburn and Sing Sing models (night-time isolation and congregate silent labour in a factory-like setting), the arrangement and exploitation of prisoners' work became absolutely central. By the i 850 s all northern US state prisons had committed to the congregate system, which brought together the ideal of making the prisoner a "silent and insulated working machine" 29 and private capital's interests in the contract system, as opposed to the public account system dominating the Pennsylvania model. Moreover, workshop-based congregate labour proved a far more efficient deployment of penal labour, at least from capital's point of view, than the artisanal production required by the outmoded Pennsylvania system, which forced prisoners to work at handicrafts in isolation in their cells. In this emergent penal regime, the imperative of productive labour superseded the revolutionary era's ideals of punishment and penitence.

In various parts of the world, local elites eagerly demonstrated their commitment to "modernity" by replicating the debate on the Auburn and Philadelphia systems. Yet, the relationship between the American "model" and the new prisons created in subsequent decades cannot be conceived as one of mere transmission and reception. ${ }^{3 \circ}$ In Europe, penal

28. G.A. Gildemeister, Prison Labor and Convict Competition with Free Workers in Industrializing America, ${ }_{1840-1890}$ (New York [etc.], I987); A.J. Hirsch, The Rise of the Penitentiary: Prisons and Punishment in Early America (New Haven, CT, 1992); E.M. McGinn, At Hard Labor: Inmate Labor at the Colorado State Penitentiary, I87I-I940 (New York, 1993); L. Goldsmith, Penal Reform, Convict Labor, and Prison Culture in Massachusetts, I800-I880 (Philadelphia, PA, 1994); M. Meranze, Laboratories of Virtue: Punishment, Revolution, and Authority in Philadelphia, I760-I835 (Chapel Hill, NC, 1996); M. Colvin, Penitentiaries, Reformatories, and Chain Gangs: Social Theory and the History of Punishment in Nineteenth-Century America (New York, 1997); R. McLennan, The Crisis of Imprisonment: Protest, Politics, and the Making of the American Penal State, I776-194I (New York, 2008).

29. The sentence was used by Elam Lynds, first warden of Auburn; quoted in W.D. Lewis, From Newgate to Dannemora: The Rise of the Penitentiary in New York, I796-I848 (Ithaca, NY, I965), p. 88.

30. For a useful survey of the historiography on prisons that makes a similar argument, see Mary Gibson, "Global Perspectives on the Birth of the Prison", American Historical Review, I I6 (201 I), pp. 1040-1063. For a survey of the literature on colonial punishment, see Sherman, "Tensions of Colonial Punishment". The most important recent studies on the history of the prison are: D.D. Arnold, "The Colonial Prison: Power, Knowledge and Penology in Nineteenth-Century India", in idem and David Hardiman (eds), Subaltern Studies VIII 
uses of convict labour continued to prevail over economic considerations. ${ }^{3 \mathrm{I}}$ Meanwhile, in the economic periphery and plantation societies, the abolition of slavery in the first half of the nineteenth century, colonial forms of government, and local dynamics strongly contributed to make race a fundamental factor in shaping peculiar and articulated regimes of punishment. These responded to the need to fix ethnically defined populations to specific territories and labour markets, including in the southern states of the US. In this context, convict labour, together with corporal punishment and the criminalization of entire populations, played a central role, since it translated both the racist assumption that the black/indigenous population would not work except under some form of compulsion and the idea of the insufficiency of imprisonment alone as a means to discipline subalterns, now often defined as inherently criminal. ${ }^{32}$

The most recent literature has given plenty of evidence of this process. ${ }^{33}$ For instance, scholars have described the nineteenth-century road-gangs

(Delhi, 1994), pp. I48-187; N. Finzsch and R. Jütte (eds), Institutions of Confinement: Hospitals, Asylums, and Prisons in Western Europe and North America, I500-1950 (Cambridge, 1996); R.D. Salvatore and C. Aguirre (eds), The Birth of the Penitentiary in Latin America: Essays on Criminology, Prison Reform, and Social Control, 1830-1940 (Austin, TX, 1996); N. Morris and D.J. Rothman (eds), The Oxford History of the Prison: The Practice of Punishment in Western Society (New York, 1998); F. Bernault (ed.), Enfermement, prison et châtiments en Afrique du I9e siècle à nos jours (Paris, 1999), revised English version: A History of Prison and Confinement in Africa (Portsmouth, NH, 2003); R.D. Salvatore, C. Aguirre, and G.M. Joseph (eds), Crime and Punishment in Latin America: Law and Society since Late Colonial Times (Durham, NC, 200I); P. Zinoman, The Colonial Bastille: A History of Imprisonment in Vietnam, I862-1940 (Berkeley, CA, 200I); Dikötter and Brown, Cultures of Confinement; M. Sen, Prisons in Colonial Bengal, I838-1919 (Calcutta, 2007); H. Johnston (ed.), Punishment and Control in Historical Perspective (Houndmills, 2008). Also relevant for this discussion: F. Snyder and D. Hay (eds), Labour, Law and Crime: An Historical Perspective (London [etc.], 1987); C. Anderson, Legible Bodies: Race, Criminality and Colonialism in South Asia (Oxford [etc.], 2004).

3r. See especially John Conley, "Revising Conceptions about the Origin of Prisons: The Importance of Economic Considerations”, Social Science Quarterly, 62 (I98I), pp. 247-258; Spierenburg, The Prison Experience, pp. I22-125.

32. On the intertwining of corporal and carceral punishment, see, for instance, D. Paton, No Bond but the Law: Punishment, Race, and Gender in Jamaican State Formation, $1780-1870$ (Durham, NC, 2004). On the later impact of criminal anthropology on the redefinition of individuals and groups as inherently criminal, see M. Gibson, Born to Crime: Cesare Lombroso and the Origins of Biological Criminology (Westport, CT, 2002); P. Becker and R.F. Wetzell (eds), Criminals and Their Scientists: The History of Criminology in International Perspective (New York, 2006).

33. M.S. Hindus, Prison and Plantation: Crime, Justice, and Authority in Massachusetts and South Carolina, $1767-1878$ (Chapel Hill, NC, 1980); W. Worger, South Africa's City of Diamonds: Mine Workers and Monopoly Capitalism in Kimberley, I867-I895 (New Haven, CT, 1987); A. Lichtenstein, Twice the Work of Free Labor: The Political Economy of Convict Labor in the New South (New York, I996); D.M. Oshinsky, Worse Than Slavery: Parchman Farm and the Ordeal of Jim Crow Justice (New York, 1996); M.J. Mancini, One Dies, Get 
in India, the industrial workshops in the Cairo Prison, and the "agricultural penitentiaries" in French north Africa and Italian Tripolitania; and they have narrated the exploitation of convict labour in Cecil Rhodes's De Beers Mining Company in Kimberley, South Africa's first industrial city, and the shibalo system through which Mozambican men and women escaping contract labour were forced to work for local public works and private enterprises and in the mines in South Africa, Rhodesia, and the Congo up to the I940s. But researchers have observed similar patterns for highly racially segregated non-colonial contexts, such as postindependence Brazil and the American South after the Civil War and the abolition of slavery.

In all these cases, convict labour proved instrumental in matching the economic interests of local and colonial entrepreneurs and authorities with a persistent racial hierarchy and mentality. This process cut across both the private and public use of prison labour, and could involve both "excarceration" beyond penitentiary walls and incarceration. Not surprisingly, then, in the American South the phasing out of the excarcerative convict lease in the late nineteenth century and the first decade of the twentieth century did not lead to a reformed system of "modern" incarceration, mimicking the northern states, but rather to the states' chain gangs. Convict labour was used then to build roads and other infrastructure or for state-controlled agricultural work, as in the infamous example of Parchman Farm in Mississippi, opened in 1904 and still notorious in the 1960s, when state authorities relied on the prison farm to break the will of the civil rights movement.

In the nineteenth century - allegedly "the age of the triumphant prison" 34 - and beyond, prison practice in most of the world therefore

Another: Convict Leasing in the American South, I866-1928 (Columbia, SC, I996); Mary Ellen Curtin, Black Prisoners and Their World: Alabama, I865-I900 (Charlottesville, VA [etc.], 2000); Ricardo D. Salvatore, "Penitentiaries, Visions of Class, and Export Economies: Brazil and Argentina Compared", in idem and Aguirre, Birth of the Penitentiary, pp. 194-223; M.A. Myers, Race, Labor, and Punishment in the New South (Columbus, OH, I 998); Rudolph Peters, "Egypt and the Age of the Triumphant Prison: Legal Punishment in Nineteenth Century Egypt", Annales Islamologiques, 36 (2002), pp. 253-285; B. O’Laughlin, "Proletarianization, Agency and Changing Rural Livelihoods: Forced Labour and Resistance in Colonial Mozambique", Journal of Southern African Studies, 28 (2002), pp. 5 I I-530; William H. Worger, "Convict Labour, Industrialists and the State in the US South and South Africa, I870-1930", Journal of Southern African Studies, 30 (2004), pp. 63-86; M. Da Passano (ed.), Le colonie penali nell'Europa dell'Ottocento (Rome, 2004), pp. 89-I28; S. Hynd, "Imperial Gallows: Capital Punishment, Violence and Colonial Rule in Britain's African Territories, c.1903-1968”, D.Phil., University of Oxford, 2007; R. Perkinson, Texas Tough: The Rise of America's Prison Empire (New York, 2008); J. Seibert, More Continuity Than Change? New Forms of Unfree Labor in the Belgian Congo, $1908-1930$ (Leiden, 201 I).

34. M. Perrot, "Délinquance et système pénitentiaire en France au XIXème siècle", Annales ESC, 30 (1975), p. 8r. See also Peters, "Egypt and the Age of the Triumphant Prison". 
largely contradicted Michel Foucault's assumption of a sudden and definitive shift from corporal to disciplinary punishment, which in fact appears to be an artefact of a small corner of the emergent, modern, capitalist economies. ${ }^{35}$ Moreover, even in these regions and states, the modern prison penitentiary coexisted with other forms of punishment. Convict labour, in the guise of both rehabilitation and punishment, remained a central feature of this more complex "coercive network". ${ }^{36}$ Indeed, within colonial empires, the rise of the prison did not negate the continuation and expansion of transportation, and often flourished alongside it. ${ }^{37}$ Both in Britain and in France, attempts to replace transportation to far-flung corners of the empire with metropolitan imprisonment and hard labour were repeatedly made, but failed because of the systematic opposition of political and economic lobbies. ${ }^{3}$ In the

35. M. Foucault, Surveiller et punir. Naissance de la prison (Paris, 1975), English translation: Discipline and Punish: The Birth of the Prison (New York, 1977). A similar thesis is put forward in D. Rothman, The Discovery of the Asylum: Social Order and Disorder in the New Republic (Boston, MA, I973); M. Ignatieff, A Just Measure of Pain: The Penitentiary in the Industrial Revolution, 1750-1850 (New York, 1978). The majority of the recent literature on the history of prisons (see previous note) is overtly critical of Foucault's thesis on this point. Earlier critiques can be found for instance in M. Perrot (ed.), L'impossible prison. Recherches sur le système pénitentiaire aux XIXe siècle (Paris, I980).

36. Sherman, "Tensions of Colonial Punishment", p. 669. For a broader discussion of the potentiality of this concept, see section two of the present article.

37. The most important studies on modern transportation in the British Empire include: R.I.M. Burnett, Hard Labour, Hard Fare and a Hard Bed: New Zealand's Search for Its Own Penal Philosophy (Wellington, 1995); C. Anderson, "Unfree Labour and its Discontents: Transportation from Mauritius to Australia, I $825-1845$ ", Australian Studies, I 3 (1998), pp. I I6-I33; C.F.E. Hollis Hallett, Forty Years of Convict Labour: Bermuda, I823-I863 (Bermuda, I999); C. Anderson, Convicts in the Indian Ocean: Transportation from South Asia to Mauritius, ${ }_{1} 8$ I $_{5-1853}$ (Basingstoke, 2000); C. Pybus and H. Maxwell-Stewart, American Citizens, British Slaves: Yankee Political Prisoners in an Australian Penal Colony, I839-I850 (Melbourne, 2000); S. Sen, Disciplining Punishment: Colonialism and Convict Society in the Andaman Islands (New Delhi, 2000); A. Brooke and D. Brandon, Bound for Botany Bay: British Convict Voyages to Australia (Kew, 2005); S. Nicholas (ed.), Convict Workers: Reinterpreting Australia's Past (Cambridge, 1989). For the French Empire see A. Zysberg, Les galériens. Vies et destins de 60000 forçats sur les galères de France, I680-1748 (Paris, I987); A. Bullard, Exile to Paradise: Savagery and Civilization in Paris and the South Pacific (Stanford, CA, 2000); P. Redfield, Space in the Tropics: From Convicts to Rockets in French Guiana (Berkeley, CA, 2000); J. Vanmai, Pilou Pilou (Paris, I 998-2002), 3 vols; N. Castan and A. Zysberg, Histoire des galères, bagnes et prisons en France de l'Ancien Régime (Paris, 2002); J. Kergrist, Les bagnards du canal de Nantes à Brest. La vie au camp de Glomel (I823-I832) (Spézet, 2003); Jean-Lucien Sanchez, "Identifier, exclure, régénérer. La relégation des récidivistes en Guyane (1885-1938)", in Marco Cicchini and Michel Porret (eds), Les sphères du pénal avec Michel Foucault (Lausanne, 2007), pp. I39-I53. For the Portuguese Empire see Coates, Convicts and Orphans; Timothy Coates, “The Imperial Prison of Luanda and 'Effective Occupation' of Angola”, Portuguese Literary and Cultural Studies, is/16 (2010), pp. 79-1 I4.

38. S. Devereux, "The Making of the Penitentiary Act, 1775-1779", Historical Journal, 42 (1999), pp. 405-433. On the history of British prisons, see S. McConville, A History of the 
nineteenth century and part of the twentieth century, therefore, an "extensive pan-imperial trade" in penal labour developed. ${ }^{39}$

In the case of Britain, this traffic responded to the new situation created by the independence of the American colonies, the abolition of slavery in the 1830 s, and later by the rise of nationalist movements in the Indian subcontinent, all of which shifted imperial flows of coerced labour and settlement. Between I 787 and I 868, with the North American colonies now closed off, British authorities shipped some 160,000 prisoners from Britain to New South Wales, Van Diemen's Land, and Western Australia. From the late eighteenth century to the mid-twentieth century, many thousands more convicts were sentenced to transportation from British India to penal settlements in the Malay Peninsula, Burma, Mauritius, and the Andaman Islands. Minor convict migrant streams also appear significant in some specific periods and in relation to particular events: for instance, a few thousand were transported from Ceylon to Mauritius and south-east Asia (I 1 I 5-I 868); 300 or 400 non-Anglo-Celtic convicts were transported from Canada, the Cape, and the West Indies to New South Wales and Van Diemen's Land; Ioo convicts were sentenced to transportation in Mauritius and sent to the Australian settlements (I825-1845); from the I830s to the I 860 s several thousand Chinese and Malay convicts from Burma were transported to the Bengal and Madras presidencies and to Bombay. For all the differences in these experiences, the operation of the penal settlements depended heavily on convicts' productive capacities, and the governance of these settlements was organized around the transportation and labour that brought them into existence in the first place. To put it another way, an account of the imperial expansions of the nineteenth-century world remains incomplete without acknowledging the centrality of penal labour to this process, and penal transportation as a key aspect of imperial sovereignty.

In the case of the French Empire, the building of prison-manufactories the maisons centrales, akin to the American penitentiaries observed by de Tocqueville and Beaumont in their I83 I visit to the US - in the period I $830-1835$, where around 300,000 prisoners were held every year under terrible conditions, did not exclude the extensive use of alternative, excarcerative punitive practices. Following the abolition of slavery in the colonies (I848), the insurrections of 1848 , and the expansion of its

English Prison Administration, 1750-I 877 (London [etc.], I981); M. DeLacy, Prison Reform in Lancashire, I700-1850 (Stanford, CA, I986); C. Emsley, "The History of Crime and Crime Control Institutions, c.1770-c.1945", in M. Maguire, R. Morgan, and R. Reiner (eds), The Oxford Handbook of Criminology (Oxford, 1994), ch. 4. On the history of French prisons, see J.-G. Petit, Ces peines obscures. La prison pénale en France, I780-I875 (Paris, I990); H. Gaillac, Les maisons de correction I830-1945 (Paris, I99I); M. Perrot, Les ombres de l'histoire. Crime et châtiment au XIXe siècle (Paris, 200I).

39. Anderson, Convicts in the Indian Ocean. 
colonial empire, the French state (under imperial or republican governance in the metropole) resorted to transportation on a massive scale. A law passed on 30 May I854 made Guyana the destination of both political and common-law bagnards; from I86I New Caledonia was added as a place of transportation, for instance for those involved in the Commune, but in I 897 all deportees and releguées - petty criminals who could be transported under a law of I885 - were transported again to Guyana. Transportation within the French Empire therefore began later than in the British case, but continued well into the twentieth century, longer than its counterpart. With deportation eventually abolished by the Front Populaire in 1938 and the last releguées returning to France in I953, a total of nearly 100,000 men and women are believed to have been transported under French penal jurisdiction, 67,000 of them to Guyana ( 52,000 deportees and i 5,000 releguées) and the rest to New Caledonia (20,000 and I0,000 respectively).

Similar patterns can be observed for the Portuguese Empire. After the independence of Brazil in I 822 a fundamental reorganization took place within its system of transportation. Convicts from Portugal, Cape Verde, Portuguese Guinea, São Tomé, and Mozambique were sent instead to the depósito in Luanda, Angola, and convicts from Angola, Portuguese India, Macau, and Timor to an analogous institution on Mozambique Island off the south-east coast of Africa. Around 20,000 convicts were exiled there from i 880 to 1932, when the system ended in Portuguese colonial Africa.

Because of their close association with deportations and the massive transfer of populations, it is tempting to interpret twentieth-century labour camps as the modern incarnation of these imperial systems of colonial transportation and punishment. We will discuss this point further in the following section. More commonly, however, research on labour camps has focused on their links with the shift to total war and with totalitarian regimes. ${ }^{40}$ Naturally, World War II has been the single largest

40. See the following notes for references in the text. Significant strands of the literature have dealt with the following other topics related to convict labour. (I) World War I, but mainly on POWs, such as in M. Spoerer, "The Mortality of Allied Prisoners of War and Belgian Civilian Deportees in German Custody during the First World War: A Reappraisal of the Effects of Forced Labour", Population Studies, 60 (2006), pp. I 2 I-I36; K. Tenfelde and H.-C. Seidel (eds), Zwangsarbeit im Bergwerk (Essen, 2005). (2) Other fascist regimes (especially Franco's Spain): R. Torres, Los esclavos de Franco (Madrid, 2000); R. Serrano and D. Serrano, Toda España era una cárcel. Memoria de los presos del franquismo (Madrid, 200I); I. Lafuente, Esclavos por la patria (Madrid, 2002); Julio Prada Rodriguez and Domingo Rodriguez Teijeiro, "El Trabajo os hará Libres: una Aproximación a la Explotación de la Mano de Obra Penal en el Ourense de Guerra y Posguerra", Minius: Revista do Departamento de Historia, Arte e Xeografía, Io (2002), pp. 209-236; C. Molinero, M. Sala, and J. Sobrequés (eds), Una inmensa prisión. Los campos de concentración y las prisiones durante la guerra civil y el franquismo (Barcelona, 2003); J.M. Gutiérrez Casalá, Colonias penitenciarias militarizadas de Montijo. Represión franquista en la Comarca de Mérida (Mérida, 2003); G. Acosta et al., El canal de los presos (1940-1962). Trabajos forzados: de la represión politica a la explotación económica (Barcelona, 2004); 
focus of research in this area, and wartime Japanese, German, and Soviet camps have attracted most scholarly attention. Japanese occupants deported I million Korean men and women and at least 40,000 Chinese to Japan, while forcing millions more civilians to work in Korea, China, and other parts of south-east Asia. ${ }^{4 \mathrm{I}}$ A relatively well-studied case is that of nearly 60,000 Allied POWs who were employed in the construction of the Siam-Burma Railway, interned together with 240,000 other POWs in more than 200 camps in different parts of occupied south-east Asia.

The literature on the Nazi system of camps is virtually unlimited. For the purpose of this article it will suffice to stress that, especially from the I990s, scholars have pointed to some issues important for the understanding of convict labour as a key aspect of the Nazi regime, beyond the usual focus on war and genocide. Among these are the following. First, while also expanding our knowledge on Jewish and political internees and prisoners, scholars have devoted more attention to other groups, such as POWs, Roma, gays, and common-law prisoners..$^{42}$ Secondly, historians of Nazism have addressed the complexity of the network of camps for POWs, civilian internees, and prisoners, together with its transformation as dictated by military, political, and economic strategies during the brief life of the Nazi regime. Thirdly, we have seen a renewed focus on the

S. Corvisieri, La villeggiatura di Mussolini. Il confino da Bocchini a Berlusconi (Milan, 2005); J. Rodrigo, Cautivos. Campos de Concentración en la España franquista, 1936-1947 (Barcelona, 2005); C.S. Capogreco, I campi del Duce. L'internamento civile nell'Italia fascista (1940-1943) (Turin, 2006); J.M. Soarez Tavarez, O campo de concentraçao do Taraffal (1936-1954). A origem e o quotidiano (Lisbon, 2007); J. Ruiz, "Work and Don't Lose Hope': Republican Forced Labour Camps during the Spanish Civil War", Contemporary European History, i 8 (2009), pp. 419-44I; Álvaro Falquina et al., "Arqueología de los destacamentos penales franquistas en el ferrocarril Madrid-Burgos: El caso de Bustarviejo”, Complutum, I9 (2008), pp. 175-195.

4I. See, for instance, R. Roychowdhury, Black Days in Andaman and Nicobar Islands (New Delhi, 2004); T.R. Sareen, Building the Siam-Burma Railway during World War II: A Documentary Study (Delhi, 2005); M. Spoerer, "Zwangsarbeitsregimes im Vergleich. Deutschland und Japan im Ersten und Zweiten Weltkrieg", in Tenfelde and Seidel, Zwangsarbeit.

42. See especially K. Orth, Das System der nationalsozialistischen Konzentrationslager. Eine politische Organisationsgeschichte (Hamburg, 1999); idem, Die Konzentrationslager-SS. Sozialstrukturelle Analysen und biographische Studien (Göttingen, 2000); M. Spoerer, Zwangsarbeit unter dem Hakenkreuz (Stuttgart [etc.], 200I); idem and J. Fleischhacker, "Forced Laborers in Nazi Germany: Categories, Numbers, and Survivors", Journal of Interdisciplinary History, 33 (2002), pp. I69-204; M. Buggeln, "KZ-Häftlinge als letzte Arbeitskraftreserve der Bremer Rüstungswirtschaft", Arbeiterbewegung und Sozialgeschichte, I 2 (2003), pp. 19-36; W. Benz and B. Distel (eds), Geschichte der Konzentrationslager 1933-1945 (Berlin, 2004), 5 vols; M. Buggeln, Arbeit und Gewalt. Das Außenlagersystem des KZ Nenengamme (Göttingen, 2009); idem, "Building to Death: Prisoner Forced Labour in the German War Economy - The Neuengamme Subcamps, 1942-1945”, European History Quarterly, 39 (2009), pp. 606-632; J. Caplan and N. Wachsmann (eds), Concentration Camps in Nazi Germany: The New Histories (London, 2010) - in this volume see especially J.C. Wagner, "Work and Extermination in the Concentration Camps", pp. I27-I 48. 
question of the alleged contradiction between ideological and economic motivations in the creation of camps, pointing to the defining role of the process of "continuous selection and replacement", based on the prisoner's ability to work, offset by both the nature of their work and by racial criteria. ${ }^{43}$ Fourthly, there was the fate of the common-law prisoners forcibly put to work and the "annihilation through labour" programme. ${ }^{44}$ Fifthly, mention should be made of the camps in the German African colonies as precedents and the fate of the colonial POWs. ${ }^{45}$ Scholars have also turned their attention to the internment of ex-collaborationists after the end of the war. ${ }^{46}$

43. A. Tooze, Wages of Destruction: The Making and Breaking of the Nazi Economy (London, 2006). For the previous debate, see U. Herbert, Hitler's Foreign Workers: Enforced Foreign Labor in Germany under the Third Reich (Cambridge, 1997); idem (ed.), National Socialist Extermination Policies: Contemporary German Perspectives and Controversies (New York, 2000); G. Aly and S. Heim, Architects of Annibilation: Auschwitz and the Logic of Destruction (Princeton, NJ, 2002).

44. See especially N. Wachsmann, “Annihilation through Labor': The Killing of State Prisoners in the Third Reich", Journal of Modern History, 7I (1999), pp. 624-659; idem, Hitler's Prisons: Legal Terror in Nazi Germany (New Haven, CT [etc.], 2004). See also P. Pédron, La prison sous Vichy (Paris, I993); G. von Frijtag, Het recht van de sterkste. Duitse strafrechtspleging in bezet Nederland (Amsterdam, 1999); A. Bancaud, Une exception ordinaire. La magistrature en France, 1930-1950 (Paris, 2002); Tamara Altman, "Les criminels de droit commun jugés par les conseils de guerre allemands durant la seconde guerre mondiale en Belgique: étude qualitative et quantitative sur base des Personalakten de la prison de Saint-Gilles", Ph.D., Université Libre de Bruxelles, 2004; C.G. De Vito, Camosci e girachiavi. Storia del carcere in Italia, 1943-2007 (Rome, 2009); Dimitri Roden, "Van aanhouding tot strafuitvoering. De werking van het Duitse gerechtelijke apparaat in bezet België en Noord-Frankrijk, I940-1944", Cabiers d'histoire du temps présent - Bijdragen tot de eigentijdse geschiedenis, 22 (2010), pp. I I $3-160$. See also the ongoing project by Anna Tijsseling on "Gevangen onder Duitse bezetting" (NIOD Institute for War, Holocaust and Genocide Studies, Amsterdam).

45. For instance, Helmut Bley, South-West Africa under German Rule I894-19I4 (London, I97I); Jürgen Zimmerer, “Die Geburt des 'Ostlandes' aus dem Geiste des Kolonialismus. Die nationalsozialistische Eroberungs- und Beherrschungspolitik in (post-)kolonialer Perspektive", Sozialgeschichte, 19 (2004), pp. 10-43; idem, "Annihilation in Africa: The 'Race War' in German Southwest Africa (1904-1908) and its Significance for a Global History of Genocide”, Bulletin of the German Historical Institute (Washington), 37 (2005), pp. 5I-58; Birthe Kundrus, "Kontinuitäten, Parallelen, Rezeptionen. Überlegungen zur 'Kolonialisierung' des Nationalsozialismus", WerktattGeschichte, is (2006), pp. 45-62; S. Conrad, German Colonialism: A Short History (Cambridge, $20 \mathrm{I}$ ). See also the papers presented at the workshop "Internment, Incarceration and Detention: Captivation Histories in Europe around the First and Second World War", Wassenaar, 3-4 November 201 I, especially in the session on "Colonial Perspectives". An important workshop on this topic had previously been organized by Stacey Hynd and Taylor Sherman in 2008 at the History Faculty in Cambridge, entitled "Coercive Networks: Violence, Punishment and the Colonial Condition". The proceedings of the two workshops have not yet been published.

46. For example Helen Grevers, "Het leven in de interneringskampen en gevangenissen voor collaborateurs na de Tweede Wereldoorlog in België en Nederland", BVNG/ABHC, 3 I (2009), pp. 30-33. 
Persistent interest in the history of totalitarianism, genocide, and the "Bloodlands" of east-central Europe has led as well to the significant expansion of research topics relating to the Soviet Gulags, especially as a system of labour "recruitment", mobilization, circulation, and exploitation (though many of these studies extend both prior to and after the war). ${ }^{47}$ Here, too, scholars have addressed the complexity of the Gulag system - 53 camps and 524 colonies in March 194I, on the eve of Soviet entry into the war - with some studies devoted to specific aspects, camps, and areas. The questions of the inmates' productivity and of the contribution of the camp system to the economy of the USSR have also been investigated, showing how some strategic sectors particularly benefited from convict labour, especially during the phase of industrialization in the I930s and in the labour mobilization during World War II. An emphasis on the "rehabilitative" function of forced labour was also characteristic of the Stalinist camps, as part of the broader ideological aim of "building the socialist man". This holds true for other socialist countries as well. ${ }^{48}$ For instance, administrative internment in Romania was mainly enforced for up to two years, but could be extended for five more years, according to the outcomes of the process of "re-education", where work played a central role. In this context, convict labour was used mainly for public works, as in the case of the Donau-Black Sea canal, started in 1949 and finally inaugurated by Nicolae Ceauşescu in 1984.

47. Among the most recent studies are: G. Armanski, Maschinen des Terrors: Das Lager (KZ und GULAG) in der Moderne (Münster, 1993); E. Bacon, The Gulag at War: Stalin's Forced Labour System in the Light of the Archives (New York, 1994); P.H. Solomon, Jnr, Soviet Criminal Justice under Stalin (Cambridge, 1996); S. Wheatcroft, "The Scale and Nature of German and Soviet Repression and Mass Killings, 1930-1945”, Europe-Asia Studies, 48 (1996), pp. I319-1353; N. Bougai, The Deportation of Peoples in the Soviet Union (New York, 1996); J.R. Harris, "The Growth of the Gulag: Forced Labor in the Urals Region, I929-3I", Russian Review, 56 (1997), pp. 265-280; D.J. Nordlander, "Origins of a Gulag Capital: Magadan and Stalinist Control in the Early i930s", Slavic Review, 57 (1998), pp. 791-8 I 2; Lynne Viola, "The Other Archipelago: Kulak Deportations to the North in 1930", Slavic Review, 60 (2001), pp. 730-755; Judith Pallot, "Forced Labour for Forestry: The Twentieth Century History of Colonization and Settlement in the North of Perm' Oblast", Europe-Asia Studies, 54 (2002), pp. I055-1083; N. Adler, The Gulag Survivor: Beyond the Soviet System (New Brunswick, NJ, 2002); A. Applebaum, Gulag: A History (New York, 2003); P.R. Gregory and V. Lazarev (eds), The Economics of Forced Labor: The Soviet Gulag (Stanford, CA, 2003); L. Viola, The Unknown Gulag: The Lost World of Stalin's Special Settlements (Oxford, 2007); A. Barenberg, "Prisoners Without Borders: Zazonniki and the Transformation of Vorkuta after Stalin", Jabrbücher für Geschichte Osteuropas, 57 (2007), pp. 513-534; S.A. Barnes, Death and Redemption: The Gulag and the Shaping of Soviet Society (Princeton, NJ, 201 I).

48. On the Soviet Gulag, see Barnes, Death and Redemption. On Romania, see I. Bălan, Regimul concentrationar din Romania 1945-1964 (Bucharest, 2000). On North Korean labour camps: K. Chol-hwan, The Aquariums of Pyongyang: Ten Years in a North Korean Gulag (Oxford, 200I); K. Yong, Long Road Home: Testimony of a North Korean Camps Survivor (New York, 2009). 
An important case of the exploitation of convicts in labour camps constructed by a self-proclaimed "socialist" regime in the name of "re-education" can be found in post-I949 China. ${ }^{49}$ As the studies of Frank Dikötter and Klaus Mühlhahn have shown, pre-communist China largely followed the path of other countries. Penal servitude, gaols, and traditional forms of punishment prevailed in the late imperial period and later overlapped with the emerging penitentiary model during the republican period. For instance, the Beijing No. I Prison, modelled after London's Pentonville (modelled, in turn, on the Pennsylvania system in the US), opened in I9I2, with its workshops (carpentry, weaving, typesetting, printing and bookbinding, tailoring, stonemasonry, and work with metal, leather, and bamboo) indicating a strong emphasis on reformation. During the Republican era, support for labour camps remained limited to the pro-Soviet milieu. It gained ground only as a pragmatic response to the specific conditions of civil war, and subsequently spread both in communist- and in nationalist-controlled territory during the I930s and early i940s.

With the proclamation of the People's Republic in 1949, however, two distinct forms of punishment - and therefore two distinct institutional systems - developed, both emphasizing the role of labour in re-education: the laogai (an abbreviation for laodong gaizao, i.e. "reform through labour"), aiming at the birth of a "new man" through the remoulding of every aspect of a prisoner's morals, ideas, and habits, but under a determinate sentence; and the laojiao (an abbreviation for laodong jiaoyang suo, i.e. "re-education through labour"), instituted in the mid-I950s, allowing the legal system to be bypassed and local governments to remove "undesirable elements" through indeterminate sentences.

Whether under militarized fascist regimes, socialist states at war or peace, or seemingly more benign forms of governance, labour camps thus mark the modern world and reprise persistent linkages of state efforts to restrict or define the limits of citizenship, mete out punishment, and

49. On Chinese prisons and camps: P.E. Griffin, The Chinese Communist Treatment of Counterrevolutionaries, 1924-1949 (Princeton, NJ, 1976); J.-L. Domenach, Chine: L'archipel oublié (Paris, 1992); H.H. Wu, Laogai: The Chinese Gulag (Oxford, 1992); J.D. Seymour and R. Anderson, New Ghosts, Old Ghosts: Prisons and Labor Reform Camps in China (Amonk, NY, 1997); Frank Dikötter, "Crime and Punishment in Post-Liberation China: The Prisoners of a Beijing Gaol in the I950s", China Quarterly, I49 (1997), pp. I47-159; idem, "Crime and Punishment in Early Republican China: Beijing's First Model Prison, 1912-1922”, Late Imperial China, 2I (2000), pp. I40-162; idem, Crime, Punishment, and the Prison in Modern China, I895-1949 (New York, 2002); idem, "The Promise of Repentance: Prison Reform in Modern China", British Journal of Criminology, 42 (2002), pp. 240-249; F. Hualing, "Re-education Through Labour in Historical Perspective", China Quarterly, I 84 (2005), pp. 8 I I-830; K. Mühlhahn, Criminal Justice in China: A History (Cambridge, MA [etc.], 2009). 
enforce work that date back to earlier historical periods. ${ }^{50}$ Indeed, far from being limited to authoritarian or totalitarian regimes, administrative detention - often coupled with forced labour - has also characterized the recent history of many Western democracies. This was especially the case in colonial contexts, and the experience in Kenya is particularly telling, although not unique, in this respect. ${ }^{51}$ As in other cases, conditions inside the detention camps created in Kenya in the rgros and I920s and in the prison camps opened in 1933 depended on the assumption that forced labour, together with corporal punishment, could actually serve as the only effective forms of penal discipline. However, the experience in Kenyan prisons and camps turned into an even more brutal experience by the end of 1954, at the zenith of the Mau Mau revolt, since police repression by far exceeded the capacity of the already overcrowded prisons, and the colonial government decided to establish a network of camps, collectively called the "Pipeline", characterized by violence, torture, and forced labour.

More recent experiences within Europe itself indicate the actuality of detention camps and point to the centrality of convict labour within them. Particularly significant are the networks of "re-education camps" for asozialen or asocialen, which functioned respectively in West Germany and the Netherlands from the late i940s to the i $9705 .{ }^{52}$ More linked to the penal system, networks of detention camps for (mainly) alcoholics existed in Scandinavian countries up until the I970s, with forced labour viewed as a central feature in the process of their "treatment". ${ }^{3}$ Moreover, it is

50. For an example from a democratic state, see Volker Janssen, "When the 'Jungle' Met the Forest: Public Work, Civil Defense, and Prison Camps in Postwar California”, Journal of American History, 96 (2009), pp. 702-726.

51. D. Branch, "Imprisonment and Colonialism in Kenya, c.1930-1952: Escaping the Carceral Archipelago", International Journal of African Historical Studies, 38 (2005), pp. 239-265; C. Elkins, Imperial Reckoning: The Untold Story of Britain's Gulag in Kenya (New York, 2005); D. Anderson, Histories of the Hanged: The Dirty War in Kenya and the End of Empire (New York [etc.], 2005).

52. A. Dercksen and L. Verplanke, Geschiedenis van de onmaatschappelijkheidsbestrijding in Nederland, 1914-1970 (Amsterdam, 1987); W. Ayass, Das Arbeitshaus Breitenau. Bettler, Landstreicher, Prostituierte, Zubälter und Fürsorgeempfänger in der Korrektions- und Landarmenanstalt Breitenau (I874-1949) (Kassel, I992); idem, "Die 'korrektionelle Nachhaft'. Zur Geschichte der strafrechtlichen Arbeitshausunterbringung in Deutschland", Zeitschrift für Nenere Rechtsgeschichte, Is (1993), pp. I84-20I; B. Maandag and T. van der Mee, De 'asocialen'. Heropvoeding in Drentse kampen (Rotterdam, 2005); Thomas Irmer, Barbara Reischl, and Kaspar Nürnberg, "Das Städtische Arbeits- und Bewahrungshaus Rummelsburg in Berlin-Lichtenberg”, 2008, www.gedenkstaettenforum.de/nc/aktuelles/einzelansicht/news/das_ staedtische_arbeits_und_bewahrungshaus_rummelsburg_in_berlin_lichtenberg/; last accessed on 6 May 2012.

53. J. Edman and K. Stenius (eds), On the Margins: Nordic Alcohol and Treatment $1885-2007$ (Oslo, 2007). 
tempting to see a historical continuity between these detention camps and some "therapeutic communities" created after the I970s, for instance in Italy, conceived as an alternative to imprisonment for drug addicts convicted of minor crimes who are then forced to work without remuneration within factories inside the closed gates of the "community". ${ }^{4}$ In a perverse inversion of colonial transportation, the present-day global landscape is also dominated by the extensive network of "detention centres" for undocumented immigrants created since the early i990s. ${ }^{55}$ Little research has been carried out on his topic, and what has is qualitatively insufficient. The apparent marginality of forced labour in those institutions, mainly used as temporary warehouses for people awaiting expulsion and deportation, therefore needs to be systematically examined, not least because the camps are rapidly differentiating and growing in number.

\section{EXPANDING CONVICT LABOUR HISTORIOGRAPHY}

The survey in the previous section indicates the potentiality of a processbased approach to the history of convict labour and thus the need to overcome the present fragmentation of research into a number of sub-disciplines and geographic areas related to single regimes of punishment. ${ }^{56}$ However, the survey also suggests the limitations of the available historiography on convict labour in at least two ways. On the one hand there exists a chronological limitation, especially as far as the pre-I 500 period is concerned. On the other hand there is an undue focus in the historiography on a more or less explicit Eurocentric approach. Both of these limitations remain bound to the unwarranted teleology of penal reform and modernization that is assumed to move progressively towards stable forms of incarceration and rehabilitation, and away from brutality, unmitigated punishment, and naked coercion or enslavement. This view imagines the labour camps of totalitarian social

54. P. Giudicini and G. Pieretti, San Patrignano tra Comunità e Società. Ricerca sui percorsi di vita di 7 I I ex-ospiti di San Patrignano (Milan, 1994).

55. See, for instance, P. Mares, Borderline (Sydney, 200I); Meaghan Amor and Janet Austin (eds), From Nothing to Zero: Letters from Refugees in Australia's Detention Centres (Melbourne, 2003); M. Dow, American Gulag: Inside US Immigration Prisons (Berkeley, CA, 2005); Jesuit Refugee Service Europe, Detention in Europe: Administrative Detention of Asylum-Seekers and Irregular Migrants (Brussels, 2005); M. Rovelli, Lager italiani (Rome, 2006); A. Kaur and I. Metcalfe (eds), Mobility, Labour Migration and Border Controls in Asia (London, 2006); Anton van Kalmthout, "Foreigners", in Miranda Boone and Martin Moerings (eds), Dutch Prisons (The Hague, 2007), pp. IoI-I 26; C. Kobelinsky and C. Makaremi, Enfermés dehors. Enquêtes sur le confinement des étrangers (Paris, 2009); M. Ford, "Constructing Legality: The Management of Irregular Labour Migration in Thailand and Malaysia", in Van der Linden and Himmelstoss, Labour History Beyond Borders, pp. 177-200; A. Sciurba, Campi di forza. Percorsi confinati di migranti in Europa (Verona, 2009). For a global view, see http://www.globaldetentionproject.org/home.html; last accessed on 6 May $20 \mathrm{I} 2$.

56. For a similar approach, see Spierenburg, The Prison Experience, ch. I I, pp. 26I-276. 
orders as the negation of modernity. This section seeks to address these two issues, in order to put forward some suggestions for the development of a more global and long-term perspective on the history of convict labour, one less prone to reifying conceptions of punishment associated with "modernity".

By extending our chronology back before i 500 , two long-term trends can be observed. The first relates to the continuity or discontinuity of the experience of penal transportation. ${ }^{57}$ The second refers to the "birth of the prison" as part of a broader shift in attitudes towards the socially marginal. Observing early modern and modern transportation, four conditions seem especially favourable for the development of penal transportation: first, centralized authority; secondly, control over large territories with an uneven distribution of resources; thirdly, a drive for (internal and/or external) colonization, often linked to military engagements; and, fourthly, fluidity between free and unfree labour. Notwithstanding the scarcity of sources and specific research, available studies on the Han Empire (206 BCE-220 CE) and on the (Western) Roman Empire (27 BCE-476 CE) reveal the consistency of these four characteristics with those ancient contexts as well. ${ }^{8}$

57. Note also that Roman law remained the basis of early modern and modern imperial law on exile and penal transportation. See, for instance, Coates, Convicts and Orphans, pp. 22-23.

58. On the Han Empire see C. Martin Wilbur, "Industrial Slavery in China during the Former Han Dynasty (206 BC-AD 25)", Journal of Economic History, 3 (1943), pp. 56-69; idem, Slavery in China During the Former Han Dynasty, 206 BC-AD 25 (Chicago, IL, 1943). For long-term surveys, see also Philip F. Williams and Yenna Wu, The Great Wall of Confinement: The Chinese Prison Camp through Contemporary Fiction and Reportage (Berkeley, CA, 2004), p. 24; R.H. van Gulik, Crime and Punishment in Ancient China: The T'ang-Yin-Pi-Shih (Bangkok, 2007); Mühlhahn, Criminal Justice in China, pp. 14-57. For a later period see J. Waley-Cohen, Exile in Mid-Qing China: Banishment to Xinjiang, 1758-I820 (New Haven, CT [etc.], 199r). On the Roman Empire see J.G. Davies, "Condemnation to the Mines: A Neglected Chapter in the History of the Persecutions", University of Birmingham Historical Journal, 6 (1958), pp. 99-107; P. Garnsey, Social Status and Legal Privilege in the Roman Empire (Oxford, I970); Fergus Millar, "Condemnation to Hard Labour in the Roman Empire, from the Julio-Claudians to Constantine”, Papers of the British School at Rome, 52 (1984), pp. I 24-147; J. Clayton Fant, "The Roman Emperors in the Marble Business: Capitalists, Middlemen or Philanthropists?", in Norman Herz and Marc Waelkens (eds), Classical Marble: Geochemistry, Technology, Trade (Dordrecht, I988), pp. I47-158; Mark Gustafson, "Condemnation to the Mines in the Later Roman Empire", Harvard Theological Review, 87 (1994), pp. 42 I-433; D. Lassandro, "I 'damnati in metalla' in alcune testimonianze antiche", in M. Sordi, Coercizione e mobilità umana nel mondo antico (Milan, 1995); J. Alexander, "Islam, Archaeology and Slavery in Africa", World Archaeology, 33 (200I), pp. 44-60 (on the possible continuation of the condemnation to hard labour in mining/quarrying). No specific information could be found on convict labour in the Assyrian Empire (I 100-600 BCE). See for instance B.J. Parker, "Archaeological Manifestations of Empire: Assyria's Imprint on Southeastern Anatolia", American Journal of Archaeology, 107 (2003), pp. 525-557; M. Liverani, Antico Oriente. Storia, società, economia (Rome, 2009). 
In the Roman Empire the damnatio ad metalla led to the transportation of convicts (damnati, or damnati in metallum) to the gold and silver mines of Numidia, the alabaster mines and the porphyry quarries of Egypt, the marble quarries on the island of Proconnesus (Marmara), and other sites in Cyprus, Sardinia, and Palestine. In the Han Empire, convicts were transported to the government salt and iron monopolies, where they staged repeated revolts in the final part of the first century BCE. In both empires the employment of convict labour was linked with the trends in the demand and supply of slaves: in the case of the Roman Empire the rise of convict labour from the third century CE onward is probably due to the reduced influx of slaves, in turn possibly caused by the end of the wars of conquest; in the Han Empire of the second and first centuries BCE the "boundless supply of cheap corvee and convict labor" 59 appears to be a key explanation for the alleged absence of slaves in some economic sectors.

Moreover, the flexibility of labour relations has been especially stressed for the Roman Empire by ancient scholars who, moving away from its traditional characterization as a "slave society", have pointed to the existence of a considerable degree of inter-changeability between the work of freemen, slaves, and freed slaves within what has been defined as a "unified labour force". ${ }^{60}$ Transported convicts could also be included in the latter. Central to this fluidity of labour relations was the "open" character of Roman slavery, marked by frequent manumissions, social mobility linked to positive incentives (salary, education, etc.), and the relatively high level of legal integration of ex-slaves into the citizenry. Similarly, the literature on the Han Empire refers to frequent general amnesties and special pardons for convicts of various classifications.

New research is certainly needed on this topic, together with greater cooperation between historians working on ancient and modern empires. However, it seems that a degree of continuity can be hypothesized between ancient, early modern, and nineteenth-century transportation. Furthermore, as suggested in the previous section, it is also tempting to propose that such continuity can be further traced between transportation and twentieth-century labour camps. Although the emphasis lies on the movement of inmates in the case of transportation, and on the locations of their final destinations in that of labour camps, transportation and camps can be seen as two different modes of a similar phenomenon of channelling and corralling the labour of subject or criminalized categories

59. Wilbur, "Industrial Slavery in China during the Former Han Dynasty", p. 66.

60. Peter Temin, "The Labor Market of the Early Roman Empire", Journal of Interdisciplinary History, 34 (2004), pp. 513-538. See also P.A. Brunt, "Free Labor and Public Works at Rome", Journal of Roman Studies, 70 (1980), pp. $8 \mathrm{I}-100$. The key reference on ancient slavery is K. Bradley and P. Cartledge (eds), The Cambridge World History of Slavery (Cambridge, 20I I), I. 
of the populace. ${ }^{61}$ To begin with, the above four conditions apply to the twentieth-century camps too. Moreover, empirical evidence also points to this long-term continuity. For instance, agricultural penal colonies created outside Lisbon soon after the end of transportation to Portuguese Africa in 1932 were later used during the Salazar regime and, at least in the case of the Colónia Penal Agricola de "António Maceira" in Sintra, continue to function to this day. ${ }^{62}$ Similarly, the long-term continuity between the Tsarist katorga and the Soviet Gulag can be understood in the context of Russian internal colonization of the eastern regions, especially once recent interpretations are taken into account that point to the deportation of millions of peasants to the "other archipelago" of the special settlements in the early 1930s. ${ }^{63}$ This holds true as well for the network of Nazi concentration and labour camps. ${ }^{64}$ In fact, deportation to Germany

6r. An earlier vein of scholarship, associated with criminologist Thorsten Sellin, posited just such continuity. See T. Sellin, Slavery and the Penal System (New York, I976), and J.M. Moore, "Classic Text Revisited: Slavery and the Penal System", Criminal Justice Matters, 85 (201 I), p. 40, for a recent retrospective appreciation of Sellin's work. One possible explanation for the different way of framing transportation and the labour camps lies in the fact that a separation exists between the historiography of transportation, prison, and labour camps in the twentieth century. Moreover, the demise of colonialism could have further accentuated this separation: Klaus Mühlhahn, on the contrary, has shown the global connections and transfers through which the concentration camps "moved" first from the European colonial domains to the European continent and later further throughout the world; "The Concentration Camp in Global Historical Perspective”, History Compass, 8 (2010), pp. 543-561. A totalization of the twentieth-century experience of the camps has followed, especially as far as the Nazi concentration camps are concerned. The twentieth century has therefore been framed as "the century of the camps", and Agamben's theory of the state of exception and of the camps has avoided any reference to colonial policy and experience, although it extensively deals with institutions of Roman law and nineteenth- and twentieth-century European politics. See J. Kotek and P. Rigoulot, Century of Concentration Camps: I00 Years of Radical Evil (London, 2004); G. Agamben, Homo Sacer: Sovereign Power and Bare Life (Stanford, CA, 1998); idem, State of Exception (Chicago, IL, 2005). Some scholars, however, have seen the seeds of the Nazi camp system in German colonial policy in Southwest Africa in the suppression of the Herero Revolt; Bley, South-West Africa under German Rule; Conrad, German Colonialism; Mühlhahn, "The Concentration Camp in Global Historical Perspective”, p. 546. When considering the long-term continuity between transportation and twentieth-century labour camps, an important issue is that of the role played by internment in both regimes.

62. Coates, Convicts and Orphans.

63. Viola, The Unknown Gulag, pp. I85-188. See also Abby M. Schrader, "Branding the Exile as 'Other': Corporal Punishment and the Construction of Boundaries in mid-NineteenthCentury Russia”, in D.L. Hoffmann and Y. Kotsonis (eds), Russian Modernity (London, 2000), pp. I9-40; Hellie Richard, "Migration in Early Modern Russia, I480s-1780s", in Eltis, Coerced and Free Migration; A.A. Gentes, Exile to Siberia, I590-I822: Corporeal Commodification and Administrative Systematization in Russia (Houndmills, 2008); idem, Exile, Murder and Madness in Siberia, I823-6I (Houndmills, 2010). This was a point made by Sellin at the time.

64. See references in n. 42 above. For an extended explanation of this hypothesis, see C.G. De Vito, "Mussolini's Prisons, Final Act (1943-1945)", paper for the European Social Science History Conference, Glasgow, I I-I4 April $20 \mathrm{I} 2$. 
during World War II could be envisaged as an integrated system providing forced and convict labour from the Reich's annexed or controlled countries to specific sites in order to serve the needs of the Nazi war economy.

This long-term perspective on transportation also poses the question of the medieval experience of convict labour. ${ }^{65}$ In fact, at least in the western European context, the Middle Ages witnessed the virtual disappearance of penal transportation. The four points mentioned above could suggest some explanations for this trend. With the reorientation of the Roman Empire towards the East, the European territory was essentially split into a series of political entities that were too many, too small, and too weak to conceive and organize the transportation of their small number of convicts. A "provincialization of politics" took place, since "local élites began to deal with the 'barbarian' powers rather than with the imperial government, which was by now too distant and decreasingly relevant" ${ }^{66}$ Moreover, the shift from taxation to landowning as the basis of the state made the post-Roman kingdoms economically less strong and less complex. The structure of the feudal economy further accentuated the fragmentation of power and territory and could be reckoned to have impeded the fluidity between different labour relations by tying surplus labour to particular plots of land. Finally, Germanic influences made weregild a prevalent form of punishment, focusing on compensation and restitution rather than transportation and forced labour.

Characteristic of the new situation in medieval Europe was also the recourse to exile rather than to transportation, that is, to a form of punishment aimed at expelling someone from a certain territory rather than sending them to another territory for forced work. Such expulsion sought primarily to cleanse and protect the body politic, rather than to deploy "surplus" population in an effort to extend the effective reach of the imperial state (though certainly these two motives could easily join together, as they came to in Britain's North American colonies). Lack of funding and facilities for long-term imprisonment can also be held responsible for this shift. Not surprisingly then, "the reappearance of penal labor in western Europe at the end of the Middle Ages coincided with the emergence of the national state and an increase in its wealth and power". ${ }^{67}$ The growing use of convict labour aboard the galleys in the

65. For the considerations that follow in the text, see W. Chester Jordan, From Servitude to Freedom: Manumission in the Senonais in the Thirteenth Century (Philadelphia, PA, 1986); P. Brown, The World of Late Antiquity, AD I 50-750 (New York, I989); C. Wickham, Framing the Early Middle Ages: Europe and the Mediterranean, 400-800 (Oxford, 2004); idem, The Inheritance of Rome: A History of Europe from 400 to 1000 (London, 2008).

66. Wickham, The Inheritance of Rome, p. 108.

67. Pike, Penal Servitude in Early Modern Spain, p. 4. 
same period confirms this, since it is first to be observed in larger and more powerful political entities such as Venice and France.

The late Middle Ages have also been seen as the origin of another long-term transformation in punishment and convict labour, one that in this case actually ran counter to the impulse to exile social malefactors. Around the thirteen century, the emergence of a new mode of production in some European urban centres and the general change in mentality led to a new attitude towards the governing of social outcasts - from expulsion to containment. ${ }^{68}$ In turn, this produced the creation of new "incarcerative" institutions - leper-houses, brothels, hospitals, almshouses, Jewish quarters - and a fundamental shift in the practice of imprisonment. Gaols - the large majority of whose population was made up of individuals imprisoned for debt - took on a more important role in city life and the urban imaginary and became internally more differentiated. This meant that carceral institutions departed from their traditional role as warehouses for individuals awaiting trial or punishment. On this basis Guy Geltner has argued for a medieval "birth of the prison", some five or six centuries before the chronology posed by Michel Foucault in Discipline and Punish.

To be sure, forced labour cannot be considered a major feature of these late medieval European prisons, but the shift in the attitude towards the socially excluded they suggested was a fundamental element in the emergence of other institutions explicitly designed to govern the urban poor and make them engage in productive or punitive labour. Examples of the latter are to be found especially in the prison workhouses - the Dutch

68. G. Geltner, The Medieval Prison: A Social History (Princeton, NJ [etc.], 2008). Particularly in the I970s and I980s a broad debate developed among historians on the shift in attitude towards poverty and the emergence of new institutions between the late Middle Ages and the early modern period. Studies on the emergence of mental asylums also played a key role in this. Michel Foucault's Histoire de la folie à l'âge classique (Paris, 196I) in many ways anticipated this debate. See, for instance, J.-P. Gutton, La société et les pawvres. L'exemple de la Généralité de Lyon, I534-I789 (Paris, I97I); O.H. Hufton, The Poor of Eighteenth-Century France, 1750-1789 (Oxford, 1974); B. Geremek, Les marginaux parisiens aux XIV et XVe siècles (Paris, 1976); idem, La potence ou la pitié. L'Europe et les pauvres du Moyen Age à nos jours (Paris, 1978); M. Mollat, Les pauvres au Moyen Age. Etude sociale (Paris, 1978); J. Le Goff, "Les marginaux dans l'Occident médiéval", Cahiers Jussieu, 5 (1979), pp. I9-28; C. Lis and H. Soly, Poverty and Capitalism in Pre-Industrial Europe (Brighton, 1979); P. Spierenburg, The Emergence of Carceral Institutions: Prisons, Galleys and Lunatic Asylums, I550-1900 (Rotterdam, 1984); S. Woolf, The Poor in Western Europe in the Eighteenth and Nineteenth Centuries (London, 1986). While often linked to a Marxist perspective on the origins of capitalism, in some authors the long-term approach was inspired by Norbert Elias's classic Über den Prozeß der Zivilisation. Soziogenetische und psychogenetische Untersuchungen (Basel, 1939), 2 vols, English translation: The Civilizing Process (Oxford, 1969 and 1982). Other authors have also referred to Gerhard Oestreich, Geist und Gestalt des frühmodernen Staates (Berlin, 1969), English translation: Neostoicism and the Early Modern State (Cambridge, 1982). 
tuchtbuizen, the German zucbtbäuser, and the English bridewells - that were created from the early seventeenth century. ${ }^{69}$ As shown by the pathbreaking research by Pieter Spierenburg, long-term shifts in mentalities and in material conditions played a role in making work a central feature of these institutions. Most importantly, the study of the workhouses leads to the following issues: the productive or non-productive character of convict labour (and the problem of its competition with free labour); the rehabilitative or punitive function of work; the specialization of space in the institutions and the differentiation within the inmate population, often through the gendered-, age-, and socially constructed concept of the "able-bodied" labourer. These questions, and the prison workhouse model as such, proved to be central in the rise of the penitentiary during the nineteenth century. ${ }^{70}$

By examining the phenomenon of convict labour within a chronology going back before I500, it is thus possible to address its role in the transition to modernity while at the same time avoiding a modernizationoriented approach that stresses a sudden transition accompanying the late eighteenth-century Industrial Revolution. ${ }^{7 \mathrm{I}}$ This approach entails a move away from teleological concepts such as "proto-industrialization" or "proletarianization" and frames convict labour as one form of labour relations involved in the process of commodification of labour. We have already explored this issue in the first section. What is important to add here is that, in order to proceed in this direction, a truly global perspective is needed, one that investigates the applicability of the scholarship on European medieval and early modern transportation, prisons, and workhouses described above to non-European experiences. For instance, what kind of

69. The key reference is Spierenburg, The Prison Experience. For a long-term approach to the history of the prison, see also X. Rousseaux, "Pour une histoire de la justice pénale en Belgique (I 3e-20e s.)", Histoire de la Justice, 8-9 (1995-1996), pp. I I 3-I 47; E.M. Peters, "Prison before the Prison: The Ancient and Medieval Worlds", in Morris and Rothman, The Oxford History of the Prison, pp. 3-43; X. Rousseaux, "Dalle città medievali agli stati nazionali: rassegna sulla storia della criminalità e della giustizia penale in Europa (I350-1850)", in L. Cajani (ed.), Criminalità, giustizia penale e ordine pubblico nell'Europa moderna (Milan, 1997); X. Rousseaux, "Historiographie du crime et de la justice criminelle dans l'espace français (1990-2005). Partie I: du Moyen-Age à la fin de l'Ancien Régime", Crime, Histoire et Sociétés, I0 (2006), pp. I23-1 58; F. Bretschneider, Gefangene Gesellschaft. Eine Geschichte der Einsperrung in Sachsen im I8. und 19. Jahrbundert (Konstanz, 2008); A. Gestrich and R. Lutz (eds), Inklusion/Exklusion. Studien zu Fremdheit und Armut von der Antike bis zur Gegenwart (Frankfurt, 2008); G. Ammerer et al. (eds), Orte der Verwahrung. Die innere Organisation von Gefängnissen, Hospitälern und Klöstern seit dem Spätmittelalter (Leipzig, 20I0); I. Heullant-Donat, J. Claustre, and E. Lusset (eds), Enfermements. Le cloitre et la prison (VIe-XVIIIe siècle) (Paris, 201 I).

70. Colvin, Penitentiaries, Reformatories, and Chain Gangs.

7I. For a clear discussion of these two interpretations, see Spierenburg, The Prison Experience, pp. I-I I. 
punitive systems and convict labour were in use in the Abbassid, Mamluk, and Ottoman caliphates, in the Vijayanagara and Inca empires, and in the Aztec Triple Alliance? ? $^{2}$

Together with the fragmentation of sub-disciplines corresponding to regimes of punishment and temporal limitations imposed by teleological assumptions of modernity and progress, the limited knowledge of non-Western areas is the other fundamental limitation of the available literature on convict labour. Moreover, not only does the historiography focus more on "the West" than on "the Rest", most of the research is marked by a Eurocentric mindset, one that takes the alleged progressive penal development of incarceration, rehabilitation, and social control associated with modernity as its template. This blind spot is in fact common to both the liberal humanitarian narrative and the critical anti-Enlightenment perspective, such as that provided by the Foucauldian approach to correctional history. Merely adding narratives of convict labour outside "the West" would then not be sufficient to move beyond this Eurocentric approach. ${ }^{73}$ A non-Eurocentric understanding can emerge only when narratives, interpretations, and concepts are reconsidered from an integrated global perspective that no longer privileges the development of Western penal history, whether as a humane model or the poisoned taproot of total bio-power.

As with many other fields of research, colonial and post-colonial studies today represent the most innovative methodological sub-discipline within the historiography of convict labour. For although they too risk reproducing a form of Eurocentrism - the history of non-European countries considered only as far as European colonization is involved - the post-colonial awareness

72. The following works deal with these contexts, but reveal the difficulty of finding specific information on convict labour: S. Falk Moore, Power and Property in Inca Peru (New York, 1958); H. Dieterich, "Some Theoretical and Methodological Observations about the Inca Empire and the Asiatic Mode of Production", Latin American Perspectives, 9:4 (1982), pp. I I I-I 32; G.W. Conrad and A.A. Demarest, Religion and Empire: The Dynamics of Aztec and Inca Expansionism (New York, 1984); M.E. Smith and F.F. Berdan, "Archaeology of the Aztec Empire", World Archaeology, 23 (1992), pp. 353-367; I. Schneider, "Imprisonment in Pre-Classical and Classical Islamic Law", Islamic Law and Society, 2 (1995), pp. I 57-I73; C.M. Sinopoli and K.D. Morrison, "Dimensions of Imperial Control: The Vijayanagara Capital", American Anthropologist, 97 (1995), pp. 83-96. From a general point of view, the importance of expanding the perspective both to the pre-1 500 period and to non-European experiences has been shown by J.L. Abu-Lughod, Before European Hegemony: The World

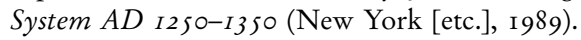

73. For a similar point about the limitations of a Eurocentric view of prison history, see Gibson, "Global Perspectives on the Birth of the Prison". In some of the I980s' and I990s' historiography on colonial prisons, for instance, the inapplicability of Foucault's Surveiller et punir scheme to the colonial systems of confinement had been observed, but it was framed in terms of the "pre-modernity" and the "backwardness" of the colonies rather than questioning Foucault's interpretation. On this see Sherman, "Tensions of Colonial Punishment". 
of the need to radically rethink Eurocentric categories allows us to reconsider convict labour within a global framework. Not surprisingly then, it is in a recent survey article on the "tensions of colonial punishment" that Taylor C. Sherman has proposed the concept of a "coercive network" as a new framework to understand the mutual connections between different regimes of punishment and the links between punishment as a whole and the political, cultural, social, economic, and administrative context on a global, or at least imperial, scale. ${ }^{74}$ Similarly, Clare Anderson, writing on the convict transportation networks in the Indian Ocean across several centuries, has pointed to the need to develop a "world history frame sensitive to the global and the local". ${ }^{75}$

As should be evident by now, this article accepts these suggestions and in turn argues that they should be extended to the study of convict labour beyond the colonial and post-colonial experience. Our view is that convict labour can provide a strategic perspective to connect research on the intersecting lines of penal history and labour history from a global perspective, much the same way transnational studies of slavery and emancipation have helped reconceptualize the study of labour in the eighteenth- and nineteenth-century Atlantic world. When studying convict labour, one should neither remain trapped within preconceived "national" borders nor imagine the "local" as a self-contained unit and the "global" as a monolithic entity. Rather, following the work of Doreen Massey, space could be visualized as "the product of interrelations", "the sphere of the possibility of the existence of multiplicity", and as something "always under construction" ${ }^{76}$ It could then be possible to "follow the traces" of different persons, ideas, and phenomena through different localities and scales. For instance, historians of convict labour could study the exchanges of personnel, techniques, and technology, investigate global responses to specific events, trace the chains of production and consumption by convicts, compare the fate of different groups of prisoners, and follow the biographies of convicts, personnel, and other historical actors. ${ }^{77}$ This is particularly true given how dependent penal networks

74. Ibid., p. 669.

75. C. Anderson, "Convict Transportation in the Indian Ocean", paper for the "Global Convict Labour" conference, IISH, Amsterdam, I3-I4 June 20I2. The awareness of the need for a global and long-term perspective is also shown by the international conference on "Colonial Places, Convict Spaces: Penal Transportation in Global Context, c.1600-1940", Department of Economic \& Social History, University of Leicester, 9-10 December 1999. The proceedings of the conference have never been published. Abstracts of the papers are available at http://iccs.arts.utas.edu.au/abstracts4.html; last accessed on 2 I May 20I 2. See also Ward, Networks of Empire, for an example of what this approach might yield.

76. D. Massey, For Space (London [etc.], 2005), p. 9.

77. The expression "follow the traces" is in Marcel van der Linden, "Historia do trabalho: o Velho, o Novo e o Global", Revista Mundos do trabalbo, i (2009), pp. i I-26. Other 
and the political economy of convict labour have been on the movement of bodies through geographic space, the reallocation of human productive power from territory to territory, or from one economic sector to another, when the "market" would not suffice. This is why attention to transportation or "excarceration", instead of incarceration alone, must be considered a central element in the history of convict labour.

Looking at convict labour beyond a rigid global/local dichotomy, the possibility also emerges to address fully human agency by a wide range of actors. In the past two decades scholars of penal history have paid significant attention to decision-making processes, interaction between various state and private authorities, and the plurality of consequences of attempts at reform. Efforts have also been made to locate the power to shape the policy of punishment and convict labour outside political and penal institutions, for example by the actions of convicts themselves, including resistance. ${ }^{78}$ However, much work remains to be done in this field.

Only a handful of scattered studies, for instance, specifically deal with the key issue of the relationship between convict labour and the labour movement. ${ }^{79}$ However, scholars have pointed to the importance of four

important methodological references are A. Lüdtke (ed.), The History of Everyday Life: Reconstructing Historical Experiences and Ways of Life (Princeton, NJ, 1995); J. Revel (ed.), Jeux d'échelles. La micro-analyse à l'expérience (Paris, I996); M. Werner and B. Zimmermann, "Beyond Comparison: Histoire croisée and the Challenge of Reflexivity", History and Theory, 45 (2006), pp. 30-50; U. Freitag and A. von Oppen (eds), Translocality: The Study of Globalising Processes from a Southern Perspective (Leiden [etc.], 2010); Van der Linden, Workers of the World, pp. 372-378 (on the concept of "teleconnections"). For examples of a biographical or prosopographical approach to this social history, see C. Pybus, "The African Diaspora at the End of the World", in Dawne Curry, Eric Duke, and Marshanda Smith (eds), Extending the Diaspora: New Histories of Black People (Urbana, IL, 2009), pp. I 57-177; I. Duffield, "From Slave Colonies to Penal Colonies: The West Indian Convict Transportees to Australia", Slavery and Abolition, 7 (1986), pp. 25-45, as well as several of the papers presented at the "Colonial Places, Convict Spaces: Penal Transportation in Global Context, c.1600-1940” conference. For a good recent example of the application of this method, see Anderson, Subaltern Lives.

78. McLennan, Crisis of Imprisonment; R.T. Chase, "Slaves of the State' Revolt: Southern Prison Labor and a Prison-Made Civil Rights Movement, 1945-1980”, in Robert Zieger (ed.), Life and Labor in the New South (Gainesville, FL, 2012); A. Lichtenstein, "Twice the Work of Free Labor? Labor, Punishment, and the Task System in Georgia's Convict Mines", in Gary Fink and Merl Reed (eds), Race, Class, and Community in Southern Labor History (Tuscaloosa, AL, 1994); Steven A. Barnes, Death and Redemption: The Gulag and the Shaping of Soviet Society (Princeton, NJ, 20I I), ch. 6; idem, “'In a Manner Befitting Soviet Citizens': An Uprising in the Post-Stalin Gulag”, Slavic Review, 64 (2005), pp. 823-850.

79. K.A. Shapiro, A New South Rebellion: The Battle against Convict Labor in the Tennessee Coalfields, I87I-I 896 (Chapel Hill, NC [etc.], I998); B. Greenberg, Worker and Community: Response to Industrialization in a Nineteenth-century American City, Albany, New York, I850-I 884 (Albany, NY, 1984). See also "The Struggle against the Introduction of Convict and Reformatory Labour into Natal", Archives Year Book for South African History (1967), 2 vols; T. Mathiesen, The Politics of Abolition (London, 1974); Gildemeister, Prison Labor and Convict Competition; McLennan, Crisis of Imprisonment; K. Morgan, "Petitions against Convict 
aspects of this relationship: first, the "disciplining effect of convict labour" on free labour; secondly, the need to look at specific productive sectors when considering the issue of economic competition between convict and "free" labour; thirdly, the importance of labour organizations in limiting convict labour to state-owned sectors and, more often, to "domestic" labour inside penal establishments; and, fourthly, that the perceived "competition" of convict labour does not simply entail economic factors, but also relates to the negative image that convict labour could have shed on a particular class of people or on a certain location. In the latter case, opposition to convict labour could typically be expected from merchants and small entrepreneurs. On the other hand, at least in the recent history of the US, punishment has served as an engine of community economic redevelopment and job creation through "carceral Keynesianism" and in privatized corrections. ${ }^{80}$

Other visible gaps in the historiography regard the custodians and the impact of imprisonment and exile on convicts' families and friends. ${ }^{8 \mathrm{I}}$ More generally, little is known about the social history and work life of the inmates before and after their internment, a lack of information that is probably due to a long-term prejudice about - and the historical invisibility of - the lumpenproletariat that has formed the vast majority of the convict population in many contexts. ${ }^{82}$ Furthermore, although

Transportation, I725-1735”, English Historical Review, I04:410 (1989), pp. I I0-1 I 3. See also the special issue of Labor: Studies in Working-Class History of the Americas (201 I), including A. Lichtenstein, “A 'Labor History' of Mass Incarceration”, Labor: Studies in Working-Class History of the Americas, 8:3 (20I I), pp. 5-I4.

80. A. Lichtenstein and M. Kroll, "The Fortress Economy: The Economic Role of the US Prison System", in Elihu Rosenblatt (ed.), Criminal Injustice: Confronting the Prison Crisis (Boston, MA, 1996); Heather A. Thompson, "Why Mass Incarceration Matters: Rethinking Crisis, Decline and Transformation in Postwar American History", Journal of American History, 97 (2010), pp. 703-734; Mike Davis, Ecology of Fear: Los Angeles and the Imagination of Disaster (New York, 1999), p. 4I6; idem, "Hell Factories in the Field: A Prison-Industrial Complex", The Nation, 260:7 (20 February 1995).

81. On prison guards see, for example, Ted Conover, Newjack: Guarding Sing Sing (New York, 2000); N. Morris, Maconochie's Gentlemen: The Story of Norfolk Island and the Roots of Modern Prison Reform (New York, 2003); F.V. Mochulsky, Gulag Boss: A Soviet Memoir (New York, 201 I); J. Page, The Toughest Beat: Politics, Punishment, and the Prison Officers' Union in California (New York, 20I I). On family and community, see, for example, Curtin, Black Prisoners and their World; W.Z. Goldman, Inventing the Enemy: Denunciation and Terror in Stalin's Russia (Cambridge, 20I I); Gheith and Jolluck, Gulag Voices, chs 7-10; Heather A. Thompson, "Rethinking Working Class Struggle through the Lens of the Carceral State: Toward a Labor History of Inmates and Guards", Labor: Working Class Studies of the Americas, 8:3 (20I I), pp. I 5-45; C.A. Frierson and S.S. Vilensky, Children of the Gulag (New Haven, CT, 20I0), chs 4-6. Attempts at a social history of penal life have been made, especially for penal colonies.

82. C. Aguirre, The Criminals of Lima and Their Worlds: The Prison Experience, I850-1935 (Durham, NC, 2005). On Marxism and lumpenproletariat see, for instance, H. Draper, "The Concept of the 'Lumpenproletariat' in Marx and Engels”, Économies et Sociétés, 6 (1972), 
quantitatively consistent for some places and periods, the literature on the labour of female convicts - around 5-IO per cent of prisoners in most societies - appears poorly integrated in general overviews of convict labour. ${ }^{83}$ Scant attention is paid to the gender dimension of penal labour as such, as well as to the importance of age and generations. Particularly noticeable is the lack of specific studies on juvenile convict labour. ${ }^{84}$

As far as the convicts' agency is concerned, the picture remains highly uneven. Much historiography has focused on political convicts subjected to penal servitude and in prisons, where work has often played a highly

pp. 2285-23 I2; F. Bovenkerk, "The Rehabilitation of the Rabble: How and Why Marx and Engels Wrongly Depicted the Lumpenproletariat as a Reactionary Force", Netherlands Journal of Sociology, 20 (1984), pp. I3-4I; P. Hayes, "Utopia and the Lumpenproletariat: Marx's Reasoning in The Eighteenth Brumaire of Louis Bonaparte", Review of Politics, 50 (1988), pp. 445-465.

83. Among the available studies: C. Lesselier, "Les femmes et la prison 1820-1939. Prison de femmes et reproduction de la société patriarcale", in J.-G. Petit, La prison, le bagne et l'bistoire (Paris [etc.], 1984); O. Krakovitch, Les femmes bagnardes (Paris, 1990); E. Campelli et al., Donne in carcere. Ricerca sulla detenzione femminile in Italia (Milan, 1992); J. Damousi, "Depravity and Disorder': The Sexuality of Convict Women”, Labour History, 68 (1995), pp. 30-45; D. Oxley, Convict Maids: The Forced Migration of Women to Australia (Cambridge, 1996); M.S. Zárate, "Vicious Women, Virtuous Women: The Female Delinquent and the Santiago de Chile Correctional House, I860-1900", in Salvatore and Aguirre, The Birth of the Penitentiary, pp. 78-100; K. Daniels, Convict Women (Sydney, 1998); E. Conlin Casella, "Doing Trade': A Sexual Economy of Nineteenth-Century Australian Female Convict Prisons", World Archaeology, 32 (2000), pp. 209-22 I; A. Pillay, "Prisoners Are Women Too: A Case Study of Women Prisoners at Westville Prison", Alternation, 7 (2000), pp. I 56-I69; M. Gibson, "Le carceri femminili nell'Italia liberale", Storica, I6 (2000), pp. I35-1 54; D.J. Guy, "Girls in Prison: The Role of the Buenos Aires Casa Correccional de Mujeres as an Institution for Child Rescue, I890-I940", in Salvatore, Aguirre, and Joseph, Crime and Punishment in Latin America, pp. 369-390; S. Sen, "The Female Jails of Colonial India", Indian Economic and Social History Review, 39 (2002), pp. 417-438; L. Mara Dodge, "Whores and Thieves of the Worst Kind": A Study of Women, Crime, and Prisons, I835-2000 (DeKalb, IL, 2002); K. Ruggiero, “'Houses of Deposit' and the Exclusion of Women in Turn-of-the-Century Argentina”, in C. Strange and A. Bashford (eds), Isolation: Places and Practices of Exclusion (New York, 2003), pp. I I I-I 24; S. Trombetta, Punizione e carità. Carceri femminili nell'Italia dell'Ottocento (Bologna, 2004); S. Leukel, Strafanstalt und Geschlecht. Geschichte des Franenstrafvollzugs im 19. Jabrhundert (Baden und Preußen) (Leipzig 2010); G. Geltner, "No-Woman's Land? On Female Crime and Incarceration, Past, Present, and Future”, Justice Policy Journal, 7:2 (2010), n.p., www.cjcj.org/files/ No_Woman.pdf; last accessed i I December 20I2; Talitha LeFlouria, "The Hand that Rocks the Cradle Cuts Cordwood': Exploring Black Women's Lives and Labor in Georgia’s Convict Camps, 1865-1917", Labor: Studies in Working-Class History of the Americas, 8:3 (201 I), pp. 47-63; J. Pallot and L. Piacentini, Gender, Geography, and Punishment: The Experience of Women in Carceral Russia (Oxford, 20I 2).

84. For some studies on juvenile convict labour, see, for example, M.-S. Dupont-Bouchat, De la prison à l'école. Les pénitenciers pour enfants en Belgique au XIXe siècle (I840-I9I4) (Kortrijk, I996); idem and E. Pierre (eds), Enfance et justice an XIXe siècle. Essais d'histoire comparée de la protection de l'enfance 1820-1914 (Paris, 200I); Castan and Zysberg, Histoire de galères; M. De Koster, "Jongeren en criminaliteit: Een lange geschiedenis van de Middeleeuwen tot heden", Tijdschrift voor Criminologie, 52 (2010), pp. 308-317; Frierson and Vilensky, Children of the Gulag, pp. 6-63. For the French case, see also the special issue of the Revue d'histoire de l'enfance irrégulière, 7 (2005). 
particular role in regimes of punishment. ${ }^{85}$ On non-political prisoners, important studies have been published on those transported across the Indian Ocean, ${ }^{86}$ and on the individual and collective resistance of internees in the Nazi lagers and in the Stalinist Gulags (also in relation to forced labour), ${ }^{87}$ but little is known about detention camps in other historical and geographical contexts. Similarly, much work has been done in recent decades on prisoner resistance to the convict lease and the chain gang in the US South in the second half of the nineteenth century, but no systematic study is available on resistance to forced labour in gaols, prisons, and penitentiaries. ${ }^{88}$ Research on the latter could certainly benefit from an interdisciplinary approach that brings together historical findings and the long tradition of sociological, criminological, and ethnographical studies on life within "total institutions". ${ }^{89}$ And comparative research

85. A preliminary question is of course that of defining "political prisoner". On this, the ongoing research by Padraic Kenney is especially relevant. For some references on political prisoners' resistance see U. Kumar Singh, Political Prisoners in India (New Delhi, 1998); Peter Zinoman, "Colonial Prisons and Anti-Colonial Resistance in French Indochina: The Thai Nguyen Rebellion, I917”, Modern Asia Studies, 34 (2000), pp. 57-98; L. McKeown, Out of Time: Irish Republican Prisoners, Long Kesh 1972-2000 (Belfast, 200I); F.L. Buntman, Robben Island and Prisoner Resistance to Apartheid (New York, 2003); P. Gready, Writing as Resistance: Life Stories of Imprisonment, Exile, and Homecoming from Apartheid South Africa (Oxford, 2003); D. Arnold, "The Self and the Cell: Indian Prison Narratives as Life Histories", in idem and S. Blackburn (eds), Telling Lives in India: Biography, Autobiography, and Life History (New Delhi, 2004), pp. 29-53; P.F. Williams and Yenna Wu (eds), Remolding and Resistance Among Writers of the Chinese Prison Camp (New York, 2006); F. Rule, Un allegro muy largo: de la vida social y cultural en las cárceles de la dictadura militar argentina, 1976-1983 (Buenos Aires, 2006); M.R. Prette (ed.), Il carcere speciale (Dogliani, 2006); C. Anderson, The Indian Uprising of 1857-8: Prisons, Prisoners and Rebellion (London, 2007).

86. See, for instance, L. Frost and H. Maxwell-Stewart, Chain Letters: Narrating Convict Lives (Melbourne, 200I); Clare Anderson, "The Bel Ombre Rebellion: Indian Convicts in Mauritius, I 8 I 5-53", in G. Campbell (ed.), Abolition and its Aftermath in Indian Ocean Africa and Asia (London, 2005), pp. 46-59; Clare Anderson, “'The Ferringees are Flying - the Ship is Ours!': The Convict Middle Passage in Colonial South and Southeast Asia, 1790-1860", Indian Economic and Social History Review, 42 (2005), pp. I43-186; idem, "Sepoys, Servants and Settlers: Convict Transportation in the Indian Ocean, I787-1945", in Dikötter and Brown, Cultures of Confinement, pp. I85-220; A.A. Yang, "Indian Convict Workers in Southeast Asia in the Late Eighteenth and Early Nineteenth Centuries", Journal of World History, I4 (2003), pp. I79-208. 87. See, for instance, Caplan and Wachsmann, Concentration Camps in Nazi Germany; Barnes, "In a Manner Befitting Soviet Citizens".

88. See, for instance, Curtin, Black Prisoners and Their World. See also C. van Onselen, "Crime and Total Institutions in the Making of Modern South Africa: The Life of Nongoloza Mathebula, I 867-1948”, History Workshop, I9 (1985), pp. 62-8 I; McLennan, Crisis of Imprisonment; Chase, "Slaves of the State' Revolt".

89. N.S. Hayner and E. Ash, "The Prisoner Community as a Social Group", American Sociological Review, 4 (1939), pp. 362-363; D. Clemmer, The Prison Community (Boston, MA, 1940); M.G. Caldwell, "Group Dynamics in the Prison Community”, Journal of Criminal Law, Criminology and Police Science, 46 (1956), pp. 648-657; G.M. Sykes, The Society of Captives: A Study of a Maximum Security Prison (Princeton, NJ, 1958); E. Goffman, Asylums: Essays on 
could reveal the role played by work and labour relations in common law prisoners' rights movements, like those that erupted in the US and in western Europe during the 1960 s and $1970 .^{90}$

The lack of attention paid to agency also appears as the major weakness of the vast sociological and political literature on the process of mass incarceration in the US and elsewhere since the 1990 s. $^{9 \mathrm{I}}$ Here, abstract and supposedly non-modifiable forces such as "globalization", "neoliberalism", and (in the US) the "prison-industrial complex" are described as imposing control on the "post-industrial proletariat", "multitudes", and "poor" through incarceration. Although these descriptions have played an important role in creating awareness of the political relevance of this ongoing process, they fail to provide a broader framework to locate it historically. Moreover, because they do not always effectively identify specific agents that either promote or resist the shift in penal policy, these accounts can produce a sense of inevitability and thus impotence. Finally, this literature typically refers exclusively to Western penal systems - and most often to the US - but generalizes its conclusions to the whole world.

the Social Situation of Mental Patients and Other Inmates (New York, 196I); T. Mathiesen, The Defences of the Weak: A Sociological Study of a Norwegian Correctional Institution (London, 1965); J.B. Jacobs, Stateville: The Penitentiary in Mass Society (Chicago, IL [etc.], I977); Falk Bretschneider, Martin Scheutz, and Alfred Stefan Weiß (eds), Personal und Insassen von "Totalen Institutionen" - zwischen Konfrontation und Verflechtung (Leipzig, 201 I).

90. Mathiesen, The Politics of Abolition; Rebelión en las cárceles (Madrid, 1978); R. Adams, Prison Riots in Britain and the USA (Houndmills, 1994); Philippe Artières, Laurent Quéro, and Michelle Zancarini-Fournel, Le Groupe d'information sur les prisons. Archives d'une lutte, 1970-1972 (Paris, 2003); César L. Rubio, "La revuelta de los comunes. El movimiento de presos sociales durante la Transición", in Por la memoria anticapitalista. Reflexiones sobre la autonomía (Madrid, 2008); H. Smits, Strafrechthervormers en hemelbestormers. Opkomst en teloorgang van de Coornhert-Liga (Amsterdam, 2008); C.G. De Vito and S. Vaiani, "Ci siamo presi la libertà di lottare. Movimenti dei detenuti in Europa Occidentale”, Zapruder, I6 (2008), pp. 8-22; Thompson, "Rethinking Working Class Struggle"; Perkinson, Texas Tough; Chase, "Slaves of the State' Revolt". For a recent example of work on the prisoners' rights movement and Black power, see D.F. Tibbs, From Black Power to Prison Power: The Making of Jones $v$ North Carolina Prisoners' Labor Union (New York, 201 I).

91. For some contributions to this debate see L. Wacquant, Les prisons de la misère (Paris, 1999); A. De Giorgi, Zero tolleranza. Strategie e pratiche della società di controllo (Rome, 2000); N. Christie, Crime Control as Industry: Towards Gulags, Western Style (New York, 2000); D. Garland (ed.), Mass Imprisonment: Social Causes and Consequences (London [etc.], 200I); R. Matthews and P. Francis (eds), Prisons 2000: An International Perspective on the Current State and Future of Imprisonment (Houndmills, 200I); D. van Zyl Smit and F. Dünkel (eds), Imprisonment Today and Tomorrow: International Perspectives on Prisoners' Rights and Prison Conditions (The Hague, 200I); P. Artières and P. Lascoumes (eds), Gouverner, enfermer. La prison, un modèle indépassable? (Paris, 2004); L. Re, Carcere e globalizzazione. Il boom penitenziario negli Stati Uniti e in Europa (Rome, 2006); Thompson, "Why Mass Incarceration Matters"; Mary Louise Frampton, Ian Haney López, and Jonathan Simon (eds), After the War on Crime: Race, Democracy, and a New Reconstruction (New York, 2008); Ruth Wilson Gilmore, Golden Gulag: Prisons, Surplus, Crisis, and Opposition in Globalizing California (Berkeley, CA, 2007). 
The same limitations characterize the way convict labour itself is approached in this strand of literature. Most frequently absent from the picture, it is otherwise depicted as an undifferentiated form of "modern slavery" in a way that suggests a regression to earlier stages of civilization. However, when contemporary convict labour is looked at through a global and comparative perspective the same intertwining of economic, social, political, and cultural factors appears that has operated in previous historical contexts. ${ }^{92}$ Moreover, as in the past, convict labour in the contemporary world is not limited to penal institutions. Labour camps, in particular, continue to play an important role, as the Chinese laojiao and laogai dramatically show.

Yet today, even while incarceration expands as a form of punishment, penal labour itself often appears redundant. The complex interaction of different factors on different scales thus points to another possibility: the forces that have led to the emergence of convict labour in certain historical contexts could actually be reversed. An analysis is thus possible of the objective and subjective factors that have led away from the exploitation of penal labour in relation to certain categories of or even all prisoners in a given time and space. Under what conditions does punishment not produce rehabilitative or retributive convict labour? Why is there no convict labour? By answering these questions, dramatic human experiences may emerge, such as exile, repatriation, extreme isolation (as in US "supermax" prisons), extermination, and genocide or attempted genocide, not to mention the more mundane tasks of simply managing "surplus" populations in a post-industrial political economy. ${ }^{93}$ But this approach might also reveal new patterns of agency, resistance, alternatives, and, perhaps, abolition.

\section{TRANSLATED ABSTRACTS \\ FRENCH - GERMAN - SPANISH}

Christian G. De Vito et Alex Lichtenstein. En écrivant une histoire mondiale du travail des prisonniers.

Dans cet essai bibliographique, les auteurs tentent d'approfondir les connaissances sur le travail des prisonniers dans une perspective mondiale et sur une longue durée. D’abord, les conditions propices à la naissance et la transformation du travail des

92. Dirk van Zyl Smit and Frieder Dünkel (eds), Prison Labour: Salvation or Slavery? (London, 1999); E. Shea, Le travail pénitentiaire: un défi européen. Etude comparée: France, Angleterre, Allemagne (Paris, 2006); J. Sarkin, "Global Prison Crisis: How Does Africa Rate?", South African Labour Bulletin, 32:5 (2008), pp. $25-27$.

93. See, for instance, J. Walston, "History and Memory of the Italian Concentration Camps", Historical Journal, 40 (1997), pp. I69-I 83; M. Frucht Levy, "The Ustaša Genocide against Serbs: I94 I-1945", in M. Neerland Soleim (ed.), Prisoners of War and Forced Labour: Histories of War and Occupation (Cambridge, 2010), pp. 89-104. 
prisonniers sont évoquées, en définissant cette forme de travail coercitif à l'intérieur de classifications élargies de relation de travail, et en discutant son lien avec le problème de la gouvernementalité. Ensuite, un panorama de la littérature spécialisée est esquissé sous la forme d'un voyage dans le temps, dans l'espace et sous différents régimes de peines. Enfin, les limites de la littérature disponible sont examinées, la possibilité d'une histoire sur une longue durée (remontant à avant l'an i 500) et mondiale du travail des prisonniers est considérée, et diverses approches théoriques et méthodologiques propres à favoriser cette tâche sont suggérées.

Traduction: Christine Krätke-Plard

Christian G. De Vito und Alex Lichtenstein. Eine Globalgeschichte der Sträflingsarbeit schreiben.

Dieser bibliographische Aufsatz versucht, aus globaler und langfristiger Sicht einen Beitrag zum Verständnis der Sträflingsarbeit zu leisten. Zunächst werden die Bedingungen angesprochen, die die Entstehung und Veränderung der Sträflingsarbeit begünstigen, in dem diese Form von Zwangsarbeit in den Kontext weitreichenderer Klassifizierungen der Arbeitsverhältnisse gestellt und ihre Beziehung zum Problem der Gouvernementalität diskutiert wird. Anschließend wird ein Überblick über die Literatur geboten, in Form einer Reise durch Zeit und Raum sowie durch verschiedene Strafregimes. Schließlich werden die Grenzen der vorliegenden Literatur diskutiert; die Möglichkeit einer langfristiger angelegten (vor I 500 ansetzenden) Globalgeschichte der Sträflingsarbeit wird ins Auge gefasst und es werden einige theoretische und methodologische Ansätze vorgeschlagen, die diesem Vorhaben dienlich sein könnten.

Übersetzung: Max Henninger

Christian G. De Vito y Alex Lichtenstein. Escribiendo una historia global del trabajo cantivo.

Este ensayo bibliográfico aspira a ser una contribución a la comprensión del trabajo cautivo desde una pespectiva global y de larga duración. Comienza por situar las condiciones que conducen a la emergencia y transformación del trabajo cautivo en un marco más amplio de clasificación de las relaciones laborales y se dialoga sobre su conexión con la cuestión de la gubernamentalidad. A continuación se lleva a cabo una panorámica de la literatura existente sobre el tema como si se tratara de un viaje a través del tiempo, del espacio y de los diferentes regímenes de castigo. Por último, se analizan las limitaciones de las obras a disposición del investigador, considerando la posiblidad de introducir una visión de mayor duración temporal (anterior a I 500), proponiendo una historia global del trabajo cautivo y se sugieren algunas cuestiones teóricas y metodológicas que puedan ir en esa dirección.

Traducción: Vicent Sanz Rozalén 